\title{
Population Structure, Life Strategies and Systematics of Phosphatocope Ostracods from the Middle Cambrian of Bornholm
}

\author{
Ingelore Hinz-Schallreuter ${ }^{1}$
}

With 10 Plates and 8 Figures

\begin{abstract}
The Middle Cambrian Borregård Member of Bornholm which is the stratigraphical equivalent to the Baltoscandian Exsulans Limestone yielded a rich and comparatively diverse ostracod fauna in its upper part. It comprises eight species out of four genera. They belong to three known subfamilies that are redefined on the basis of special characters of the contact margin. An ontogenetic character unknown from typical ostracods is documented in several species: during early ontogeny the gestalt ( $1: \mathrm{h}$ ratio) develops constantly in becoming increasingly longer until the so-called ontogenetical turning point (OTP) from which the direction of growth focusses on carapace height. This phenomenon may be explained by changes in body morphology. The Borregård association represents an ecologic community type differing from other yet recorded Middle Cambrian communities in the Baltoscandic region. Apart from Vestrogothia longispinosa which is a common faunal element in Baltoscandian ostracod faunas, the yet recorded species of Bidimorpha are unknown from other Baltoscandian occurrences. Vice versa, the known species of Bidimorpha described from Swedish occurrences have not been recognized in the rich Borregård community. Similarly, Falites insula and Hesslandona abdominalis may be of local significance, too, but the respective records from contemporaneous Swedish localities are insufficient in this respect, yet. Due to specific morphological adaptations, the four genera are assumed to represent different benthic life strategies. New taxa are: Bidimorpha arator $\mathrm{n}$. sp., Bidimorpha labiator n. sp., Bidimorpha sexspinosa n. sp., Falites insula n. sp., Hesslandona abdominalis n. sp., Vestrogothia herrigi n. sp. and Vestrogothia minilaterospinata n. sp.
\end{abstract}

Key words: Ostracods, Middle Cambrian, Baltoscandia, systematics, community ecology, population structure, life strategies.

\section{Kurzfassung}

Aus dem mittelkambrischen Borregård Member von Bornholm, einem zeitlichen Äquivalent des baltoskandischen Exsulanskalkes, wurde eine reiche und vergleichsweise diverse Ostrakodenfauna gewonnen. Sie umfaßt 8 Arten aus vier Gattungen, die drei bereits bekannten Unterfamilien zugeordnet werden können. Basierend auf neuen Erkenntnissen hinsichtlich der Ausbildung des Kontaktrandes werden die drei Unterfamilien neu definiert. Außerdem wird an mehreren Arten eine spezielle Entwicklung während der Ontogenese aufgezeigt, die von „echten“ Ostrakoden nicht bekannt ist. In einem frühen Stadium der Ontogenese wachsen die Schalen vor allem in die Länge, bis sich bei einer bestimmten Größe, dem ontogenetischen Umkehrpunkt (OTP), die Wachstumsrichtung ändert und dann vor allem in die Höhe gerichtet ist. Dieses Phänomen ist vermutlich an morphologische Veränderungen der Weichkörperanatomie gekoppelt. Die Borregård-Fauna repräsentiert eine besondere Vergesellschaftung, die sich von anderen mittelkambrischen Ostrakodenassoziationen Baltoskandiens deutlich unterscheidet. Abgesehen von Vestrogothia longispinosa, dem häufigsten baltoskandischen Ostrakodenvertreter, zeichnet sich die Borregård-Gemeinschaft durch zwei Arten von Bidimorpha aus, die von anderen baltoskandischen Lokalitäten nicht bekannt sind. Umgekehrt konnten keine der schwedischen Arten von Bidimorpha im Borregård Member nachgewiesen werden. Auch Falites insula und Hesslandona abdominalis haben möglicherweise lokale ökologische Bedeutung; diesbezüglich sind aber vergleichbare Daten aus dem baltoskandischen Raum noch unbefriedigend. Die spezifischen morphologischen Gehäuseausbildungen bei den untersuchten vier Gattungen deuten darauf hin, daß es sich um Adaptationen für unterschiedliche benthische Lebensweisen handelt.

\section{Introduction}

More than 30 years ago, Müller (1964) described a new group of Cambrian ostracods for which he introduced the term Phosphatocopina according to the assumed primary phosphatic carapaces.
He discovered these ostracods in etched residues in the course of conodont picking. Most of his yet published material was described as new taxa except for Aristozoe? minima Kummerow, 1931 which had been recorded from the isle of Öland.

\footnotetext{
1 Museum für Naturkunde, Institut für Paläontologie, Invalidenstraße 43, D-10115 Berlin, Germany. e-mail: ingelore.hinz-schallreuter@rz.hu-berlin.de Received March 1998, accepted May 1998
} 
Concerning Hesslandona necopina Müller, 1964 Schallreuter (pers. comm. 1980) pointed out, that the oldest documentation of a phosphatocope ostracod goes back to Steusloff's (1895) Bythocypris polita which appeared to be a senior synonym of Hesslandona necopina Müller, 1964. Subsequently, Müller (1982: 279) considered Bythocypris polita as a nomen oblitum which was, however, rejected by well-proven arguments by Schallreuter (1984: 2).

Müller (1964) recorded ostracods with a maximum length of $1.75 \mathrm{~mm}$ which he considered to be adults (1. c.: 4). By contrast, Hinz-Schallreuter (1993c: 407) proved that phosphatocopes could reach a length of up to $1 \mathrm{~cm}$. Further evidence was given by several records of Beyrichia angelini Barrande, 1872 from various Swedish localities that turned out to belong to phosphatocope ostracods. With these findings, phosphatocope documentation in Baltoscandia dates back almost 150 years, starting in 1855 with Beyrichia angelini, that proved to be a collective name for different taxa.

Within his suborder Phosphatocopina Müller (1964) distinguished two new families: the monotypic Hesslandonidae and the Falitidae comprising the genera Falites, Vestrogothia and Reticulocambria. The latter genus was considered a nomen dubium because it proved to be merely a preservational state (Müller 1990: pers. comm.; Hinz-Schallreuter 1993c: 395). According to Müller, the main difference between the two phosphatocopid families was the development of a dorsal bar flanked by a nullidont (adont) hinge in the Hesslandonidae (Müller 1982: 276). In his previous paper, Müller (1964) used the term "dorsum". Since this term was already used in another sense (Jaanusson 1957: 186), Hinz (1991: 69) introduced the term "interdorsum" for this particular sculpture. Investigations during the last decade proved that the interdorsum was a common feature of all phosphatocope ostracods. It gradually decreases in width from the Lower Cambrian via Middle Cambrian until its complete disappearance in the Upper Cambrian in dependance of the simultaneous increasing of the lateral compression of the ostracod body (Hinz 1993). The interdorsum was described as a new significant sculpture by Müller (1964), but the oldest example of an interdorsum goes more than a century back to Jones (1872). He illustrated Leperditia vexata Hicks, 1871, but described this ostracod as a "... larval trilobite ...". Apparently, he erroneously interpreted the interdorsum as the pleural segment of a trilobite.
The illustrated Leperditia vexata may belong to Shergoldopsis Hinz-Schallreuter, 1993. By contrast, some authors such as Shu (1990) and Melnikova (1990) consider the interdorsum to be a "third valve". This interpretation, however, has to be rejected because a proper valve has a free margin, while the interdorsum is a completely immobile part of a carapace.

Phosphatocope ostracods were first discovered in Baltoscandia and subsequently recorded not only from other European countries such as England (Rushton 1978, Hinz 1987), but also from North America (Landing 1980), China (Zhang 1987, Shu 1990), Australia (Hinz 1991, 1992, Hinz \& Jones 1992), and Siberia (Müller et al. 1995). Additionally, some previously described taxa from North America and England have been recognized as phosphatocope ostracods, such as Polyphyma marginata Ulrich \& Bassler, 1931, Dielymella? trituberculata Lochman \& Hu, 1960, and Shergoldopsis vexata (Hicks, 1871). Representatives of the group are still unknown from South America, Africa and Antarctica.

Phosphatocopes from Cambrian sediments of Bornholm were first observed by Grönwall (1902). From the Middle Cambrian Paradoxides davidis Zone, he described the species Beyrichia Angelini Barrande var. armata. Since this species name was already occupied for a Devonian ostracod from Thuringia (Richter 1863: 672), HinzSchallreuter (1993a) introduced Bidimorpha bidimorpha n. gen. n. sp. for the taxon from Bornholm. Some twenty years after Grönwall's records, Poulsen (1923) discovered another species from the Upper Cambrian Olenus stage, which he published as Polyphyma angelini. Later, the respective specimens were established as Cyclotron poulseni n. sp. (Gründel \& Buchholz 1981). The third species, Vestrogothia longispinosa, was introduced by Kozur (1974). It also comes from an erratic boulder at Sellin (Rügen) and may be derived from Bornholm, but precise stratigraphic data are unknown. Particularly during the last two decades, Berg-Madsen recorded some ostracods from several divisions of the Middle Cambrian of Bornholm. She mentioned archaeocope ostracods from both the calcareous Borregard and the marly Kalby Members (Berg-Madsen 1981: 223, 226, tab. 1), as well as a hesslandonid ostracod from the Andrarum Limestone. Apart from the large non-phosphatocope Eremos primordialis with $9 \mathrm{~mm}$ carapace length, she reported another hesslandonid "... with spines at the posterior-ventral rim of the valves ..." from 
the Upper Alum Shale (Berg-Madsen 1985b: 141). The phosphatocope association from the Borregård Member at Øleå documented in this paper belongs to the largest ever studied phosphatocope faunas from the Middle Cambrian.

\section{Material and Methods}

The material comes from the Borregard Member of Bornholm, regarded to be an equivalent to the Middle Cambrian Exsulans Limestone of Scandinavia (Berg-Madsen 1981). The latter occurs in two different facies on the isle of Bornholm: the Kalby Member represents the marly facies at the rivulet Læså and the calcareous facies at the rivulet Øleå has been called the Borregard Member. The latter is a finegrained light to medium grey limestone which contains variable amounts of glauconite and pyrite. Bedding planes exhibit much fossil hash. Comparable to most of the Scandinavian Cambrian deposits, the sequence is rather condensed, and only about $10-25 \mathrm{~cm}$ thick. Since the limestones crop out within the rivulet $\emptyset$ leå, successful sampling is facilitated by very low water levels (for locality data see Berg-Madsen 1981).

Until now more than $20 \mathrm{~kg}$ of rock material was dissolved by 10 per cent acetic acid, and three different fractions ( 0.06 $-0.2-0.5-3.0 \mathrm{~mm}$ ) were picked under a binocular. Contrary to Berg-Madsen's (1981: 225) statement that "The Borregård Member contains trilobites and brachiopods but remarkably few microfossils" the recently assembled fauna comprises thousands of lingulate inarticulate brachiopods, trilobite and echinodermal skeletal remains, molluscs, hyoliths (tubes and opercula), hyolithelminths, phosphatocope ostracods, conodonts, sponge spicules, coeloscleritophorans, onychophoran remains, and a number of taxa of uncertain affinities (Hinz-Schallreuter 1997a). The faunal components occur almost exclusively as phosphatic hard parts. Specimens of certain primary phosphatic origin include valves of lingulate brachiopods, conodont sclerites and phosphatocope ostracods, the latter group having incorporated phosphatic matter within their organic outer lamella.

Secondary phosphatisation is an obvious phenomenon and observable in more or less complete coatings (e.g., Pl. 1: 7). Contrary to the partly thickly-coated contemporaneous Georgina fossils in Australia, the coatings within the Borregard Member are generally quite thin and do not hide original shell characters. These coatings also led to the preservation of other, previously calcareous hard parts, such as molluscan shells with precisely reflected sculpture (Hinz-Schallreuter $1995,1997 \mathrm{~b})$. The same refers to the stereome of echinodermal sclerites. However, soft integument preservation has been observed only in the inner lamella of very few specimens (e.g., Pl. 1: 3, Pl. 8: 8). This implies a fairly quick secondary phosphatisation, but obviously not as quick as the one in the Upper Cambrian Ørsten arthropods that may posses a completely preserved body morphology.

Quite frequently observed is the occurrence of phosphatocope carapaces that are crumpled to different degrees. These specimens are considered to represent a more or less demineralized state shortly before or after the hatching process rather than being the result of primary diagenetic deformation.

The ostracod fauna of the Borregård Member yields a great number of very small instars. However, due to the absence of lobal elements at that early developmental stage, an assignment at the species level is hardly possible.

The specimens illustrated in this paper have been coated with a gold-palladium alloy and stereo-photographed by both a CamScan II (Hamburg) and a Jeol scanning electron microscope (Berlin). They are housed in the Museum für
Naturkunde der Humboldt-Universität zu Berlin (MB.) under the numbers $O .251-327(311-320)$ are unfigured specimens).

\section{The Borregård community}

The collected samples represent carbonatic sedimentation of a shallow marine environment, contrary to the contemporaneous Kalby Marl at the rivulet Læså which represents a deeper water environment. The Borregård Member is a very condensed sequence of maximally $10-25 \mathrm{~cm}$ thickness. Its fossil content is irregularly spread with local enrichments, particularly of trilobite fragments. The faunal association is highly diverse and consists of brachiopods, echinodermal remains, gastropods, pelecypods, hyolithids, trilobites and also coeloscleritophoran and sponge spicules.

Although represented by more than 2000 individuals, ostracods are not a major faunal element of the Borregård community. They are vastly outnumbered by echinoderms and brachiopods. The latter are the most common faunal element. The brachiopods belong exclusively to the inarticulate Lingulata and represent various acrotretid and paterinid taxa. Trilobite remains are generally disarticulated and often appear as coquina. However, they do not reflect a high-energy environment comparable to that of the Middle Cambrian Monastery Creek Phosphorite Formation of the Georgina Basin, Australia (see Walossek et al. 1993). They are more or less in-situ findings enriched by the sparse sedimentation. The generally excellent preservation of all fossil remains is an additional indicator for a lowenergy environment. The joint occurrence of all ontogenetic stages of phosphatocope ostracods is not a reliable indicator for low-energy conditions because material of the Middle Cambrian of the Georgina Basin, Australia which shows the same phenomenon, is current-washed. However, a few findings of ostracod clusters strongly suggest in-situ burial. The agglomerates are composed exclusively of small instars belonging to a single species. Agglomerates have been recognized as Vestrogothia longispinosa (Pl. 8: 4) and Bidimorpha labiator (Pl. 8: 3). The individuals within an agglomerate are of various sizes, so that the clusters apparently represent different moulting stages and not merely members of the same hatch. It is assumed that the respective juveniles developed in special niches until they achieved a certain growth stage that enabled them to compete with the adults. 
The Borregård community as a whole is extremely rich and diverse. Apart from Vestrogothia longispinosa, this community comprises Bidimorpha arator and Bidimorpha labiator, while the younger Andrarum Limestone of Sweden is characterized by Bidimorpha bidimorpha and Bidimorpha inversa, as well as by representatives of the genus Cyclotron that has not yet been recorded from the Borregard Member. Whether part of it, in particular the vestrogothiine ostracod fauna, may be of local or stratigraphical significance is yet unclear. Comparative studies of precisely contemporaneous sediments of both regions remain to be done.

Boring organisms are also represented in the Borregârd community. Two types of traces that extend either parallel or perpendicular to the surface of ostracod valves have been discovered; the respective organisms are, however, still unknown. The first type consists of meandering traces parallel to the surface affecting either the outer (PI. 9: 2-3) or the inner surface of the valves (Pl. 9: 1). They resemble so-called solution traces ("Solutionsspuren") produced by thallophytes. Such traces were first described on Silurian leperditiocpes (Langer 1973: 18-19). Schallreuter (1983: pl. 26(12), Fig. 5) observed similar traces on Ordovician ostracodes, and Hinz-Schallreuter (1993c: 405) recorded respective traces on Cambrian phosphatic ostracods.

The second type appears as paired holes, only on the outer side of the valves. The diameter of the openings ranges between 3-6 $\mu \mathrm{m}$ (Pl. 9: 4). It is presently unknown whether the paired arrangement originates from separate more or less $\mathrm{U}$-shaped traces or whether several pairs are connected by endolithic tunnels.

The ostracod valves are considered to have been affected by boring organisms postmortally. However, the meandering traces seem to originate from a time shortly after death and prior to phosphatisation (Pl. 9: 1-3), while the second type apparently originates from a time after phosphatisation because the traces penetrate the phosphatic coating (Pl. 9: 4).

\section{Population structure of phosphatocope ostracods}

The Borregård phosphatocopes belong to the family Hesslandonidae which comprises the three subfamilies Falitinae, Hesslandoninae and Vestrogothiinae. Vestrogothiines are the most abundant component, with Vestrogothia longispinosa as the most frequent faunal element that is re- presented by more than 1500 carapaces and isolated valves. It thus makes up 80 per cent of the entire ostracod association. By contrast, Falites is recorded with about 100 individuals, about 6.6 per cent. It is followed by Bidimorpha arator and $B$. labiator which are even less frequent with 50 discovered specimens, each forming 3.3 per cent of the association. The least frequent component is Hesslandona with only eight specimens that correspond to 0.5 per cent (Fig. 1).

The size-record of Bidimorpha arator ranges between 0.5 and $2.66 \mathrm{~mm}$ in length. Similar values have been observed in Bidimorpha labiator, with the smallest instar $0.55 \mathrm{~mm}$ long and the largest approximately $2.4 \mathrm{~mm}$. Falites ranges between 0.45 and $1.7 \mathrm{~mm}$ in length. The occurrence of adult individuals cannot be proven with certainty. Among the vestrogothiine Cyclotron Rushton, 1969 isolated valves up to $1 \mathrm{~cm}$ in length are known (Hinz-Schallreuter 1993c). These specimens, however, were discovered on split surfaces of rock rather than in etched residues. The shell is extremely thin and fragile considering the unusual length of the valves which prevent them from surviving the preparation process without damage. The largest complete carapaces or valves of the Borregard community are only about $2.5 \mathrm{~mm}$ long. They probably represent larger juveniles to preadult stages rather than proper adults.

Within a single taxon, the individual growth stages are strongly represented by small to middle-sized larvae. The smallest larvae occur in rather poor quantities and even more sparse are the largest documented stages, whether they are larger juveniles or preadults.

Sexual dimorphism is a characteristic of some vestrogothiine taxa. It has been recognized in

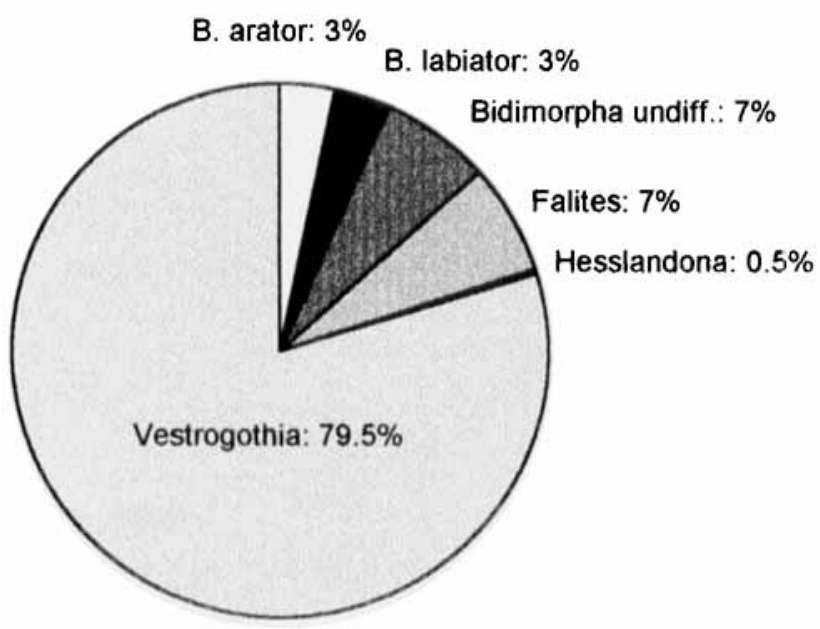

Fig. 1. Relative frequency of the different ostracod taxa in the Borregard community 
Vestrogothia longispinosa and Bidimorpha bidimorpha, the latter not being a component of the Borregård community. Contrary to most postCambrian ostracods, sexual dimorphism occurs already in the preadult stage, but not in very small instars (comp. Hinz-Schallreuter 1993a, c). This is in contrast to Zhang's (1987) documentation of Phaseolella dimorpha. According to Zhang's presented ontogenetical diagram, the taxon splits into two sexes at a very early stage, but this seems to indicate the presence of different species rather than dimorphic characters (Hinz-Schallreuter \& Koppka 1996: 40-41). However, comparable to findings on some Cambrian taxa, an example of preadult sexual dimorphism has been recorded from the Ordovician Tetradella Ulrich, 1890 (Guber 1971). Heteromorphs appear first in the A-2 stage with an increasing number of heteromorphs during later growth. Among the adults the tecnomorphs are far outnumbered by the heteromorphs. The reason for this unbalanced sex ratio is unclear. It has been explained as the possible result either of environmental factors, or of alternating syngamy and parthenogenesis although parthenogenesis of marine ostracods is unknown, yet. In the Cambrian Vestrogothia longispinosa, the individual growth stages are not detectable, but within the recorded size-range from $0.22 \mathrm{~mm}$ to $2.4 \mathrm{~mm}$ in length, heteromorphs appear first at a carapace length of around $0.9 \mathrm{~mm}$. At this comparatively early stage, heteromorphs represent only 10 per cent of the number of recorded tecnomorphs of similar size. At about $1.5 \mathrm{~mm}$ in length, tecnomorphs and heteromorphs already occur in a ratio of $2: 1$, a distinct increase in the number of heteromorphs.

\section{Life strategies among phosphatocope ostracods}

The Borregård community comprises four morphological types of ostracods that probably each represent a different benthic life strategy. According to gross morphological features, probably none of the taxa had good swimming abilities. Apart from the elongate lateral outline, the ventral margin is often posteroventrally concave, like in Vestrogothia and Bidimorpha, which suggests a crawling rather than a swimming mode of life. However, even in taxa with a well-rounded ventral margin, such as Falites and Hesslandona, the typical anterodorsal sulcation which indicates strong antennular muscles like in oepikalutid and other bradorine ostracods (Hinz-Schallreuter 1993c, Hinz-Schallreuter \& Jones 1994) is absent.

Among the spined vestrogothiines, the genus Vestrogothia is characterized by a strong lateral spine on each valve. Like in most spined ostracods, e.g., Cytheropteron or the Palaeozoic Winchellatia (comp. Triebel 1941: 335), the lateral processes of Vestrogothia are directed posteriorly. The spines are considered to have served as cantilevers that enabled the individuals to achieve greater stability when moving or resting on the ground. In soft-bottom conditions, the cantilevers may have also prevented the animals from sinking into the sediment. Pterygocythereis, e.g., lives on soft ocean bottoms. The development of a distinct ventral lappet in each valve is a means to keep the carapace agape in two places while the body is enclosed. This kind of carapace differentiation guarantees permanent water exchange and thus oxygen supply, like in Late Devonian pachydomellids (Becker 1981: 40-41; 1988). Ilyocypris may serve as another post-Cambrian example for such a mechanism. The contact margin of one valve of Ilyocypris shows small calcareous bars perpendicular to the ventral margin. These bars prevent tight closure of the valves and allow water currents to enter the carapace. Pedicythere with its increased oxygen need is another Extant example for such carapace modifications. The respective need for the Baltoscandian taxa results from reduced oxygen conditions at the sediment/water interface which they compensate with primary ventral openings.

The genus Bidimorpha also shows such characteristics. However, contrary to Vestrogothia, this genus is marked by ventral spines which distinctly interlock in the closed carapace position. On one hand these spines may have served as clausal sculptures in order to prevent a lateral shift of the valves. On the other hand, the spines are straightly downward directed in the moderately opened carapace position thus permitting anchorage in the sediment. When digging for food, water and unwanted matter could leave the carapace easily through the ventral openings. In some respect, Bidimorpha arator may be compared with both the Permian Lamellacratia Kozur, 1985 and the Cenozoic Aratrocypris Whatley et al., 1985 which are also characterized by a plough-like carapace modification, which is unique among ostracods and considered to represent an adaptation for a certain mode of life. However, in Aratrocypris and Lamellacratia, the plough is located at the anterior end, thus probably being a means for food gathering. By contrast, Bidimorpha arator has its plough-like 
spine at the posterior end of the right valve which may suggest an anchor function which might have protected the animals from being suck from behind by predatory worms.

Contrary to vestrogothiines, Falites and Hesslandona are unspined genera. Falites has a rather simple carapace morphology with particularly flat marginal surfaces that lack any differentiation. However, its longitudinal cross-section is distinctly tear-shaped and thus very much hydrodynamically developed. A similar shape is, e.g., known from the Extant Paradoxostoma which lives attached to seaweed and falitid ostracods may represent a similar mode of life, except for the fact that their soft-integument anatomy characterizes them as filter-feeder contrary to the sucking Paradoxostoma. Since falitids lack any means to compensate reduced oxygen conditions at the sediment/water interface it is likely that they lived in some distance to the seafloor. The same refers to Hesslandona which is characterized by a broad ventral surface. The latter probably served as some sort of stabilisator on the seafloor, but Hesslandona is assumed to have lived on the bottom only for more or less short intervals. Its swimming abilities probably were very poor.

A general character of all phosphatocopes is that the acroidal or interdorsal spines, respectively, are stronger in small juveniles than in larger stages, and this may be interpreted as some sort of larval defence. The spines seem to be too weak to have served as a swimming device comparable to those of the small larvae of the Middle Cambrian Monasterium opiki Fleming, 1973 (Hinz 1992).

\section{Systematic Position}

In the course of their first description, phosphatocopes were assigned to Subclass Ostracoda (Müller 1964). Most of the previous records although they were not yet recognized as phosphatocopes -- refer to ostracods. Other assignments have been suggested by Jones (1872), with his designation of phosphatocopes as a questionable larval trilobite, as well as by Holm (1893), Gürich (1929), Ulrich \& Bassler (1931), and Kummerow (1931) who considered all Cambrian ostracod-like animals as conchostracans or phyllocarids. This opinion was mainly based on special carapace features that did not agree with conditions known from post-Cambrian to Extant ostracods.
After the discovery of phosphatocopes with preserved soft integument, Müller originally defended the opinion that "... the preserved soft organs now prove with certainty that Hesslando$n a$ is an ostracode" (Müller 1981: 147) and that the "... short body with seven pairs of appendages and general similarities indicates its assignment to the Ostracoda" (Müller 1982: 276). One year later (he still considered them as ostracods; Müller 1983: 94) he agreed with Jones \& McKenzie (1980) who "... treated the Phosphatocopina as an early, short-lived ostracod group" (Williams et al. 1994: 123). More recently, however, the ostracod nature became increasingly questioned by Müller \& Walossek (1991: 283), Müller et al. (1995: 112), Walossek \& Müller (1992: 309), and Hou et al. (1996: 114-121). In the last paper, the authors delivered some arguments to suggest that phosphatocopes do not belong to the Ostracoda. However, no alternative assignment was offered, not even a group was suggested to which phosphatocopes should be more closely related. The authors merely considered them as "stem-group Crustacea" or ".... stem-group derivatives close to the crowngroup Crustacea", designations of no value for systematic descriptions.

Concerning the earliest recognized phosphatocope larva Hou et al. (l. c.) stated "... that it has four pairs of appendages rather than three ...". This statement, however, does not provide a proof that the earliest recorded larva is equivalent to the nauplius. Secondly, it is unclear whether or not brood care occurred in Cambrian ostracods with a possible first moult still within the carapace of the respective adult, in accordance to observations made on Extant Cyprideis and Xestoleberis species (comp. Hartmann 1966: 526). Hou et al. (l. c.) further referred to the minute first antenna which they regard as an autapomorphic character. The same argument was already used by Müller \& Walossek (1991: 283), who stated that the Swedish phosphatocopes were characterized by strongly reduced first antennae and undifferentiated postmandibular limbs. According to Hartmann (1992: pers. comm.), the development of individual appendages is highly variable in ostracods and strongly dependent on their mode of life. Thus, appendage morphology is not at all a means by which these Cambrian organisms should be excluded from Ostracoda. The same can be said of the undifferentiated postmandibular limbs which are considered a primitive character (comp. HinzSchallreuter 1993a: 348). According to the small 
number of appendages, the latter have multiple and often highly specific functions. Equally developed appendages may serve for completely different functions and vice versa. This phenomenon makes their homologisation highly complicated (Hartmann 1992: pers. comm.). Misinterpretation of the soft-integument anatomy led Müller et al. (1995: 104) to state that the Australian bradoriids and/or phosphatocopines were unable to swim because they lack exopodites on all post-antennular limbs, contrary to the Ørsten phosphatocopes (Walossek et al. 1993: 11). However, Hinz-Schallreuter (1993c: 440) already documented good swimming abilities at least for the bradoriid Oepikalutidae from the Middle Cambrian of Australia, shown not only by strong antennular muscles but also by highly setate antennae of the respective group.

The general carapace morphology and, in particular, the development of an interdorsum doubtlessly characterize the Phosphatocopa as a special early offshoot in ostracod evolution (see also Müller 1982: 276). Certain deviations in both carapace and soft body morphology are almost a matter of course rather than unusual characters. Unless it is clearly proved that phosphatocopes and another non-ostracod group are more closely related to one another the systematic exclusion of phosphatocopes from the class Ostracoda has to be rejected. Based on current information of the Cambrian representatives of the group, our new understanding of ostracods requires a new diagnosis. This has been also suggested for the Crustacea as a whole (Wills et al. 1955: 209). With regard to this concept, Phosphatocopa are considered as a superorder of their own, comparable to the Superorder Podocopamorphes which comprises all "true" ostracods, except myodocopids. The precise systematic position of all other Cambrian ostracods which have been united in the Archaeocopa is still unclear. Among the Archaeocopa, there are some Australian and Chinese bradoriid taxa that closely resemble true ostracods rather than phosphatocopes. These particular bradoriids exhibit typical ostracod characters such as a truly bivalved and completely closed carapace with a well-developed hinge sculpture, acroidal spines and cytoidal reticulation. Other taxa such as Houlongdongella show distinct differences to post-Cambrian ostracods and may be more closely related to other so-called Larger Bivalved Arthropods (LBA).

In their new "Evolutionary classification" Hou \& Bergström (1997: 111-112) assigned the archaeocope groups discussed above to three quite different taxa. They united the Agnostida and the Phosphatocopida in the class Pseudocrustacea; the latter and the Class Crustacea (Ostracoda) build up the Superclass Crustaceomorpha, and the Order Bradoriida is found under "Classes uncertain" within the new Superclass Proschizoramia. This concept is definitely not agreed with. Particularly when comparing phosphatocope and bradorine characters with those of post-Cambrian and Extant ostracods their common roots are most obvious (e.g., Hinz 1993, Vannier 1995, McKenzie, pers. comm. 1998) which confirms their assignment to the Class Ostracoda. A detailed discussion, however, is beyond the scope of this paper.

\section{Systematic palaeontology}

\section{Morphological terminology}

Clausal sculptures: Contact mechanisms of both dorsal and ventral sides

Gestalt: Length/Height $(1: \mathrm{h})$ ratio; see Tab. 1

Lappet: Bow-shaped projection of ventral margin (comp. Pl. 5: 1b, Pl. 8: 4b)

OTP: Ontogenetical Turning Point: size (length) of valve/carapace at which a distinct change in the development of the gestalt is observable Size: See Tab. 2

Subclass Ostracoda Latreille, 1802 emend. 1806 Superorder and Order Phosphatocopa Müller, 1964 emend. Schallreuter, 1984

Table 1

Definition of the gestalt according to Schallreuter 1967: 631.

\begin{tabular}{ll}
\hline $\mathrm{L}: \mathrm{H}$ & Term \\
\hline$<1.45$ & very high \\
$1.45-1.55$ & high \\
$1.55-1.65$ & rather high \\
$1.65-1.75$ & moderately high \\
$1.75-1.85$ & moderately long \\
$1.85-1.95$ & rather long \\
$1.95-2.05$ & long \\
$>2.05$ & very long
\end{tabular}

Table 2

Definition of the size according to Schallreuter 1987: 39.

\begin{tabular}{ll}
\hline Carapace length & Term \\
\hline$<0.5 \mathrm{~mm}$ & very small \\
$0.5-1 \mathrm{~mm}$ & small \\
$1-2 \mathrm{~mm}$ & medium-sized \\
$2-5 \mathrm{~mm}$ & large \\
$>5 \mathrm{~mm}$ & very large
\end{tabular}


Synonyms:

Hesslandonina Müller, 1982

Vestrogothiina Müller, 1982

Hesslandonocopina Müller, 1982 emend.

McKenzie, Müller \& Gramm, 1983

Vestrogothicopina Müller, 1982 emend.

McKenzie, Müller \& Gramm, 1983

Type-genus: Hesslandona Müller, 1964 (des. by Hinz-Schallreuter 1993c: 395).

\section{Families: Hesslandonidae Müller, 1964 Ulopsidae Hinz-Schallreuter, 1993}

Diagnosis: Very small to large $(0.125 \mathrm{~mm}-$ at least up to $9.3 \mathrm{~mm}$ ). Shell presumably primarily phosphatic, but often secondarily phosphatized. Carapace with broad interdorsum which may be more or less reduced or totally absent. According to Müller (1979) and Müller \& Walossek (1991), body attached to carapace along its entire length. A small abdomen may be developed. First antennae may be reduced, postmandibular limbs undifferrentiated. Appendages of larger larvae and adults unknown.

Occurrence: Cambrian; Australia, Baltoscandia, China, England, North America, Siberia, ? Iran.

Remarks: The Borregård community yields a lot of very small larvae which lack any diagnostic features, except for Vestrogothia longispinosa. For this reason, taxonomic assignments for any other than the species described herein have not been attempted.

\section{Family Hesslandonidae Müller, 1964}

Diagnosis: Medium-sized to very large, at least up to $9.3 \mathrm{~mm}$. Gestalt (l:h ratio) very high to very long. Outline distinctly preplete to distinctly postplete; sometimes with ventricular concavity. Maximum width, without consideration of nodes, generally in dorsal half of valve. Dorsal half with three nodes of which two are located in the anterior portion, and another node close to the posterodorsal cardinal corner. The $1: \mathrm{h}$ ratio increases during early ontogeny, producing an elongated lateral outline. However, from a certain size (OTP) onward, the l:h ratio decreases, resulting in a greater height of the valves.
Remarks: Hesslandonids are characterized by a fairly constant development of the three dorsal nodes. By contrast, the nodes in ulopsids are rather variable in size, pronounciation and position. In general, Ulopsidae differ from Hesslandonidae in several features. Ulopsis is characterized by a relatively high gestalt, an amplete outline, carapaces that have the greatest convexity developed in the ventral half, a large anterior node $\left(\mathrm{N}_{1}\right)$ and a rather large $\mathrm{N}_{2}$ in the centrodorsal part of the valve. $\mathrm{N}_{2}$ is located in the posterodorsal corner; it is small and weak. The narrow marginal rim is evenly developed and flattened (Hinz 1991: pls. 70, 72). By contrast, the other representative of the family, $T u$ bupestis, has a more elongate, but also amplete outline. $\mathrm{N}_{1}$ is indistinctly split into two nodes, $\mathrm{N}_{2}$ is weaker than $\mathrm{N}_{1}$, and it is also located centrodorsally, but further from the dorsal margin than the $\mathrm{N}_{1} \cdot \mathrm{N}_{2}$ is also small and weakly developed. The maximum convexity of the valve is just below mid-length comparable to Ulopsis, but the marginal surface is almost orthocline (Hinz \& Jones 1992; pls. 10, 12). The third ulopsid genus, Semillia, is rather elongate, subamplete and nearly nodeless (Hinz 1992: Pl. 19, 14, Fig.1). Contrary to both Ulopsis and Tubupestis, the left valve of Semillia is slightly larger than the right one.

Within the Suborder Phosphatocopina Müller, 1964 which was established on the basis of their phosphatic shells, the family Hesslandonidae was originally erected by Müller (1964: 21) for ostracods with a "double hinge", i.e. an interdorsum. Later, (Müller 1982: 279) raised the taxon to the rank of suborder within the Order Phosphatocopida. However, based on the evidence of rich and well-preserved material, the interdorsum proved to be the characteristic feature of all phosphatocope ostracods (Hinz 1991: 233; HinzSchallreuter 1993).

The three subfamilies Hesslandoninae, Falitinae and Vestrogothiinae are distinguished herein mainly by the typical and constant development of the marginal surface, the free margin and the contact margin which seem to be diagnostic for these taxa.

Plate 1. 1-2. Hesslandona abdominalis n. sp. 1. Holotype, carapace (MB.O. 251), right lateral (a), ventral (b), anterior (c) and dorsal views (d); $1=1.28 \mathrm{~mm}$. 2. Paratype, carapace (MB.O. 252), right lateral (a) and ventral views (b); $1=1.39 \mathrm{~mm}$. 3-7. Vestrogothia longispinosa Kozur,1974. 3. Incomplete right valve (MB.O. 253), interior view; $1=1.27 \mathrm{~mm}$. Note phosphatized crumpled inner lamella. 4. Anteriorly incomplete left valve (MB.O. 254), interior view; $1=1.33 \mathrm{~mm}$. Note rests of doublure in posterior part. 5. Anteriorly and posteriorly incomplete left valve (MB.O. 55), dorsal view; $1=1.12 \mathrm{~mm}$. Note rests of doublure in ventral part. 6. Fragmentary left valve (MB.O. 271), interior view; $1=1.17 \mathrm{~mm}$. Note doublure in ventral half. 7 . Carapace (MB.O. 257), dorsal view; I = $1.24 \mathrm{~mm}$ 


Subfamily Falitinae Müller, 1964

Diagnosis: Carapace equivalved. Gestalt of adults and larger instars mostly very high to rather high. Outline subamplete to postplete. Hinge-line straight with or without weak interdorsal spines. Free marginal rim smooth and evenly developed, lacking ornamental spines. Along the inner side of the free margin, a broad doublure is developed. Marginal surface forms a rather low angle with contact plane, it may be flattened and separated from the rest of the valve by a weak comarginal furrow. Maximum convexity of valves in dorsal half. Lobation consists of a maximum of three subdorsal nodes; $\mathrm{N}_{1}$ and $\mathrm{N}_{2}$ are located in the anterior half of valve and $\mathrm{N}_{2}$ occurs close to the posterodorsal corner. Ventral half of valve lacking any lobal elements.

Re marks: Adults and larger ontogenetic stages of the type species Falites fala have a very high to high gestalt, a distinct postplete outline in the adult stage, a distinct obliquely elongate anterodorsal $\mathrm{N}_{1}$, and a weaker $\mathrm{N}_{2}$ close to the posterodorsal corner. $\mathrm{N}_{2}$ is extremely weak and located just behind $\mathrm{N}_{1}$. Maximum convexity of the carapace is just above mid-height. The doublure, reflected by the outer marginal surface, is very broad posteriorly, flattened and set off from the rest of the valve by a semisulcus-like furrow.

\section{Genera: Falites Müller, 1964 Trapezilites Hinz-Schallreuter, 1993}

Occurrence: Middle and Upper Cambrian; Baltoscandia, ? China (Shu 1990a: 66), England, North America.

\section{Genus Falites Müller, 1964}

Type species: Falites fala Müller, 1964

Diagnosis: Medium-sized with subamplete to postplete outline. Lobation consists of distinct $\mathrm{N}_{1}$, close to dorsal margin. One or two smaller tubercle-like nodes may be developed close to the posterior-cardinal corner.

Further species:

Falites cycloides Müller, 1964

Falites angustiduplicatus Müller, 1964

?Falites pateli Landing, 1980

Hesslandona unisulcata Müller, 1982

Falites insula n. sp.
Occurrence: As for the genus.

Falites insula n. sp.

Pl. 2; Pl. 8, fig. 1; Fig. 2, Tab. 3

Derivation of name: From insula (Latin): isle, after the occurrence on the isle of Bornholm.

Holotype: Carapace, MB.O. 258, Pl. 2:1a-c

Type locality and type horizon: Same as for Hesslandona abdominalis.

Material: $>100$ carapaces and valves.

Dimensions and proportions: See Tab. 3.

Diagnos is: Length up to at least $1.73 \mathrm{~mm}$. Gestalt high to moderately high, with l:h ratio between 1.49-1.73. Interdorsum relatively broad, taking half of valve width. Outline amplete. Posterior cardinal angle somewhat larger than anterior-cardinal angle; accordingly, a weak retral swing is developed. Lobation consists of a large oval $\mathrm{N}_{1}$, its long axis directed towards anterodorsal corner. Posteriordorsally to $\mathrm{N}_{1}$, a smaller tubercle-like $\mathrm{N}_{2}$ is developed. A third still smaller
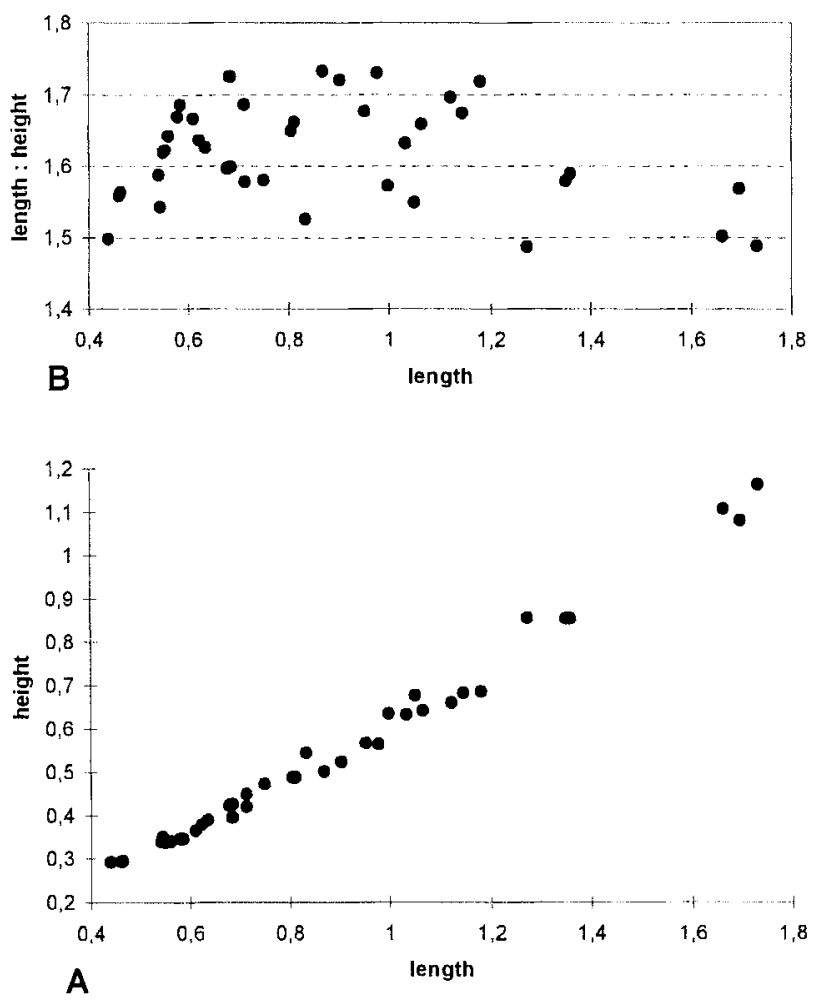

Fig. 2. Ontogeny of Falites insula. A. length/height diagram, B. gestalt diagram

Plate 2. Falites insula n. sp. 1. Holotype, posteroventrally incomplete carapace (MB.O. 258), left lateral (a), ventral (b; anterior: left), and dorsal (c) views, the latter with anterior to the right right; $1=1.70 \mathrm{~mm}$. 2. Paratype, carapace (MB.O. 259), right lateral view (b); $1=0.75 \mathrm{~mm}$. 3. Paratype, carapace (MB.O. 260), right lateral (a) and dorsal (b; anterior: left) views; $1=$ $1.18 \mathrm{~mm}$. 4. Paratype, carapace (MB.O. 261), right lateral (a) and ventral views (b); $1=0.98 \mathrm{~mm}$. 5. Paratype, carapace (MB.O. 262), left lateral (a) and ventral views (b); $1=0.59 \mathrm{~mm}$. 6. Paratype, carapace (MB.O. 263), right lateral view; $1=0.58$ $\mathrm{mm}$. 7. Paratype, anterodorsally incomplete carapace (MB.O. 264), right lateral view; $1=1.73 \mathrm{~mm}$. 


Table 3

Dimensions and proportions of Falites insula n. sp.

\begin{tabular}{llllll}
\hline Cat. no. & Specimen & Pl.: Fig. & $\begin{array}{l}\mathrm{L} \\
(\mathrm{mm})\end{array}$ & $\begin{array}{l}\mathrm{H} \\
(\mathrm{mm})\end{array}$ & $\mathrm{L}: \mathrm{H}$ \\
\hline 264 & $\begin{array}{l}\text { carapace } \\
\text { paratype }\end{array}$ & $2: 7$ & 1.73 & 1.2 & 1.49 \\
258 & $\begin{array}{l}\text { carapace } \\
\text { holotype }\end{array}$ & $2: 1$ & 1.7 & 1.1 & 1.57 \\
260 & $\begin{array}{l}\text { carapace } \\
\text { paratype }\end{array}$ & $2: 3$ & 1.18 & 0.69 & 1.72 \\
261 & $\begin{array}{l}\text { carapace } \\
\text { paratype }\end{array}$ & $2: 4$ & 0.98 & 0.56 & 1.73 \\
259 & $\begin{array}{l}\text { carapace } \\
\text { paratype }\end{array}$ & $2: 2$ & 0.75 & 0.47 & 1.58 \\
304 & $\begin{array}{l}\text { LV } \\
\text { paratype } \\
\text { carapace }\end{array}$ & $2: 5$ & 0.59 & 0.37 & 1.61 \\
262 & $\begin{array}{l}\text { paratype } \\
\text { carapace } \\
\text { paratype }\end{array}$ & $2: 6$ & 0.58 & 0.35 & 1.67
\end{tabular}

$\mathrm{N}_{3}$ occurs close to the posterior-cardinal corner close to dorsal rim. OTP at about $0.7 \mathrm{~mm}$ (Fig. 2).

Description: Largest measured valve $1.73 \mathrm{~mm}$ long. Gestalt of larger carapaces high to rather high (see Tab. 3). Dorsal margin long and straight. Anterior-cardinal angle very slightly blunt, posterior-cardinal angle equally developed or slightly exceeding anterior one (Pl. 2: 5), thus forming a weak retral swing as in the holotype, although the outline is usually amplete or subamplete. The interdorsum is broadest anteriorly at the same level of the $\mathrm{N}_{1}$, slightly tapering posteriorly. Anterior end more strongly developed than posterior portion of interdorsum. Interdorsal width measures about half of valve width at $\mathrm{N}_{1}$. Interdorsal or acroidal spines indistinct. Free marginal rim evenly developed with broad symmetrically developed doublure along inner side (Pl. 8: 1). Free marginal area of valve relatively flat to even; the area may be broader and more flattened posteriorly than anteriorly (Pl. 2: 6-7). Valves are of approximately equal size without distinct overlap and with straight contact margin (Pl. 2: 1b, 4b, 5b). Convexity of valves generally moderate, both maximum convexity and width in anterior half of valve, slightly above mid-height. Maximum width achieved by $\mathrm{N}_{1}$ or the domicilium posteroventrally to $\mathrm{N}_{1}$. Among all lobal elements, $N_{1}$ is most developed. It has an elongate shape with an anterodorsal to posteroventral extension. Posterior-dorsally of $N_{1}$ and distinctly in front of mid-length, a smaller $\mathrm{N}_{2}$ is developed. The smallest node is $\mathrm{N}_{3}$ in the posterodorsal re- gion, located closer to the dorsal rim than the two anterior nodes. Outer surface smooth or with weak tuberculation as in the holotype.

Ontogeny: The ontogenetical diagram displays no separation between the individual stages (Fig. $2 \mathrm{~A})$. For this reason, the number of instars remains unclear. Typically for hesslandonids, the gestalt becomes increasingly slender during early ontogeny and then distinctly higher during later growth. This characteristic change in shape is recognizable in carapaces about $0.7 \mathrm{~mm}$ long, and marked by the so-called ontogenetical turning point (OTP) (Fig. 2B).

Comparison: Falites fala from the Upper Cambrian zone 5 differs from $F$ insula in its smaller size-range, its higher gestalt and slightly lower OTP (comp. Fig. 2B and Hinz-Schallreuter 1996: Fig. 2). Also, F. fala is more postplete, and the carapace is less convex and more flattened posteriorly. Furthermore, an interdorsum is completely lacking (Hinz-Schallreuter 1996: Pl. 23, 90-92), and the doublure is asymmetrically developed, being broadest posteriorly. Falites unisulcatus, which ranges from the upper Middle Cambrian to the Upper Cambrian zone 1, is characterized by a distinct interdorsum, comparable to $F$. insula. It differs from the latter, however, in having only a single, but distinct, node in the more strongly flattened marginal area and in its tuberculate outer surface (Müller 1982: pl. 7, Fig. 4; Hinz-Schallreuter 1993c: Figs 7.1a,b). Falites cycloides, that comes from the Upper Cambrian zone 5 shares with $F$ insula size-range and number of nodes, but differs in the higher gestalt $(l: h=1.25)$ and in that $N_{2}$ and $N_{3}$ are of the same size as $\mathrm{N}_{1}$ (Müller 1964: pl. 5, Figs 5a,b).

Remarks: $F$. insula, $F$. unisulcatus and $F$ fala seem to represent a phyletic lineage. Apart from the general trend of phosphatocopes to reduce their interdorsum, the main trend from Middle Cambrian via lower Upper Cambrian to upper Upper Cambrian taxa is the increasing flattening of the marginal area which may suggest a certain ecologic adaptation (see chapter Life strategies).

\section{Subfamily Hesslandoninae Müller, 1964}

Diagnosis: Inequivalved with one valve overlapping. Gestalt generally elongate. Outline usually preplete, sometimes postplete. Dorsal half with three nodes (for numbering of nodes see Fig. 3 and Hinz-Schallreuter 1993a: Fig. 1) of which $N_{1}$ and $N_{2}$ are located in the anterior half and $\mathrm{N}_{2}$ close to posterodorsal corner. Lateral 
surface without nodes or lobal spines in ventral portion. Marginal surface relatively steep. Free marginal rim smoothly developed.

\section{Ge n e r a : Hesslandona Müller, 1964 Comleyopsis Hinz, 1993}

Occurrence: Lower to Upper Cambrian; Baltoscandia, England.

Remarks: Comleyopsis is the earliest yet recorded representative of the phosphatocope phyletic lineage. The broad laterally convex interdorsal borders that run parallel and gradually approach each other in stratigraphically somewhat younger taxa suggest a closer relationship to Hesslandona than to the Middle Cambrian Schallreuterina Hinz-Schallreuter, 1993 from Australia that has an upwardly arched interdorsum. Comleyopsis has therefore been removed from the family Schallreuterinidae Hinz-Schallreuter, 1993.

\section{Genus Hesslandona Müller, 1964}

Type species: Hesslandona necopina Müller, 1964 (OD).

Diagnosis: Interdorsal borders parallel to each other over entire length of dorsal margin. Lobation consists of three distinct dorsal nodes.

Further species:

Bythocypris polita Steusloff, 1895

Dielymella? trituberculata Lochman \& Hu, 1960

Hesslandona kinnekullensis Müller, 1964

Hesslandona reichi Hinz-Schallreuter, 1993c

Hesslandona abdominalis $\mathrm{n} . \mathrm{sp}$.

Occurrence: Middle to Upper Cambrian; Baltoscandia, North America.

Re marks: Hesslandona? ventrospinata Gründel in Gründel \& Buchholz, 1981 belongs to the genus Cyclotron Rushton, 1969. Hesslandona unisulcata Müller, 1982 is a member of Falites.

\section{Hesslandona abdominalis n. sp.}

Pl. 1, figs 1-2; Pl. 9, fig. 3; Pl. 10, fig. 1; Tab. 4

1985 Hesslandonid ostracode (new species ?) - Berg-Madsen: 140; Figs $5 \mathrm{~A}-\mathrm{D}$

1993c Hesslandona reichi ssp. n. A - Hinz-Schallreuter: 399

Derivation of name: From abdomen (Latin): belly, referring to the inflated anterior portion of the valve.

Holotype: Carapace, MB.O.251, Pl. 1: 1a-d.

Type locality: Stream bed of rivulet $\emptyset$ lea, the type local ity of the Borregård Member, southwest of Borregård, isle of Bornholm (Berg-Madsen 1981: Fig. 7).

Type horizon: Exsulans Limestone (Borregård Member), Triplagnostus gibbus Zone (Paradoxissimus Stage), Middle Cambrian (comp. Berg-Madsen 1981: Fig. 2).

Material: 8 carapaces.

Dimensions and proportions: See Tab. 4.
Diagnosis: Carapace inequivalved. Length without dorsal spines at least up to $1.88 \mathrm{~mm}$. Gestalt high to moderately high, with $1:$ h ratios between 1.53-1.76. Outline postplete. Valves strongly inflated in the anterior two thirds of the length. $\mathrm{N}_{1}$ and $\mathrm{N}_{2}$ nearly equally in size and distance from the dorsal margin. Convexity of nodes lower than ventral part of the domicilium below nodes. $\mathrm{N}_{3}$ weaker than anterior nodes and located immediately below dorsal rim.

Description: Inequivalved; largest measured valve $1.88 \mathrm{~mm}$. Gestalt high to moderatly high. Free marginal rim smoothly developed with strong $L / R$ overlap in the anterior and ventral parts. Outline distinctly postplete. Interdorsum relatively small, taking only about one third of the entire carapace width. "Hinges" almost parallel to each other, converging towards either end and passing into strong acroidal spines of which the anterior one may be a little more raised. Cardinal corners distinct. Anterior cardinal angle slightly blunt; posterior cardinal angle just exceeding the anterior one. Valves strongly inflated in the anterior two thirds, posteriorly slightly flattened. At dorsal flank of inflation, two almost equally-sized nodes are developed. They are located at the same distance from the dorsal rim. A third node occurs directly at the dorsal margin, slightly in front of the posterior cardinal corner.

Re marks: $1.17 \mathrm{~mm}$ long, the type species Hesslandona necopina Müller, 1964 from the Upper Cambrian zone 1 of Sweden is smaller than $H$. abdominalis, has an amplete outline and smaller

Table 4

Dimensions and proportions of Hesslandona abdominalis n. sp.

\begin{tabular}{|c|c|c|c|c|c|}
\hline Cat. no. & Specimen & Pl.: Fig. & $\begin{array}{l}\mathrm{L} \\
(\mathrm{mm})\end{array}$ & $\begin{array}{l}\mathrm{H} \\
(\mathrm{mm})\end{array}$ & $\mathrm{L}: \mathrm{H}$ \\
\hline 326 & $\begin{array}{l}\text { carapace } \\
\text { paratype }\end{array}$ & 10: 1 & 1.88 & 1.07 & 1.76 \\
\hline 252 & $\begin{array}{l}\text { carapace } \\
\text { paratype }\end{array}$ & $1: 2$ & 1.39 & 0.91 & 1.53 \\
\hline 315 & $\begin{array}{l}\text { carapace } \\
\text { paratype }\end{array}$ & unfig. & 1.29 & 0.79 & 1.74 \\
\hline 251 & $\begin{array}{l}\text { carapace } \\
\text { holotype }\end{array}$ & 1: 1 & 1.275 & 0.76 & 1.68 \\
\hline 314 & $\begin{array}{l}\text { carapace } \\
\text { paratype }\end{array}$ & unfig. & 0.805 & 0.46 & 1.74 \\
\hline 313 & $\begin{array}{l}\text { carapace } \\
\text { paratype }\end{array}$ & unfig. & 0.44 & 0.275 & 1.60 \\
\hline 312 & $\begin{array}{l}\text { carapace } \\
\text { paratype }\end{array}$ & unfig. & 0.395 & 0.245 & 1.61 \\
\hline 311 & $\begin{array}{l}\text { carapace } \\
\text { paratype }\end{array}$ & $9: 3$ & 0.38 & 0.23 & 1.64 \\
\hline
\end{tabular}


nodes. Additionally, these nodes occur in slightly different positions: the $\mathrm{N}_{2}$ is slightly more ventrally located than the $\mathrm{N}_{1}$, and $\mathrm{N}_{2}$ is not as close to the dorsal margin as in H. abdominalis (comp. Müller 1964: pl. 1, Fig. 2). Hesslandona? kinnekullensis Müller, 1964 from the Upper Cambrian zone 2 of Sweden has a recorded length of only $0.7 \mathrm{~mm}$, is thus distinctly smaller than $H$. abdominalis, and lacks any nodes. It may either represent a smaller instar of $H$. abdominalis with undeveloped nodes or it belongs to a different genus such as ?Aparchona Hinz-Schallreuter, 1993. Apart from its smaller length of $0.86 \mathrm{~mm}$, H. reichi Hinz-Schallreuter, $1993 \mathrm{c}$ from an Andrarum Limestone geschiebe of Gislövshammar (Scania) is more elongate than $H$. abdominalis. Its $1: h$ ratio, ranging between 1.95 and 2.20 , suggests a long to very long gestalt. Its outline is amplete and the valves are characterized by a prominent $\mathrm{N}_{2}$. Veldotron bratteforsa (Müller, 1964) is inflated in a similar way as $H$. abdominalis, but differs from the latter in both its amplete outline and posteroventral concavity (HinzSchallreuter 1993c: Fig. 9.2a).

The ostracod carapace from the Andrarum Limestone illustrated by Berg-Madsen (1985: Fig. 5) seems to belong to Hesslandona abdominalis. According to Fig. 5A in Berg-Madsen 1985a, (non 1985b) the carapace is $0.71 \mathrm{~mm}$ long; the carapace in her Fig. 5D measures $0.58 \mathrm{~mm}$. The latter figure shows the characteristical postplete outline of the carapace, which is, however, incomplete anterodorsally. The specimen is illustrated from a left lateral view rather than from a right lateral view, as was stated by Berg-Madsen (1985a: 139).

\section{Subfamily Vestrogothiinae Kozur,1974}

$=$ ? Cyclotronidae Gründel in Gründel \& Buchholz, 1981

Diagnosis: Large, up to at least $9.3 \mathrm{~mm}$. Carapace inequivalved with valves overlapping each other by interlocking ventral spines. Gestalt of adults and larger larvae elongate. Outline mostly distinctly preplete. Lateral surface with up to six nodes or lobal spines: three are located subdor-
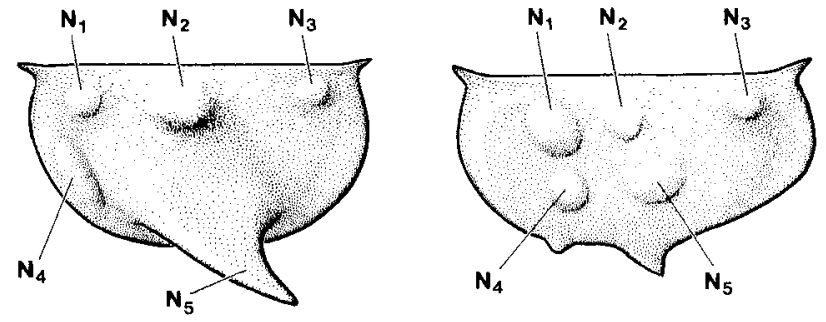

Fig. 3. Gross morphological characters of Vestrogothia and Bidimorpha. Numbering of the nodes differs slightly from that suggested in Hinz-Schallreuter 1993a (Fig. 1). The new material shows the presence of lobes $\mathrm{N}_{3}$ and $\mathrm{N}_{4}$ in Vestrogothia, so that $\mathrm{N}_{4}$ of Hinz-Schallreuter 1993a, Fig. 1B is now regarded as $\mathrm{N}_{5}$ which may also incorporate $\mathrm{N}_{6} . \mathrm{N}_{6}$ of Bidimorpha in Hinz-Schallreuter 1993a Fig. 1A is equivalent to $\mathrm{N}_{5}$ here

sally, the other nodes occur in the ventral half of the valve. Marginal surface steep. Ventral free marginal rim of both valves with overlapping ornamental spines or lappets.

Remarks: In both Vestrogothia and Hesslando$n a$, certain features were extremely overemphasized in previous studies. In 1964 , they were originally distinguished at the generic level (Müller 1964), but gradually they were raised to the rank of families, suborders and even orders in more theoretical papers (Müller, 1982; McKenzie et al. 1983). However, thorough investigation of a rich

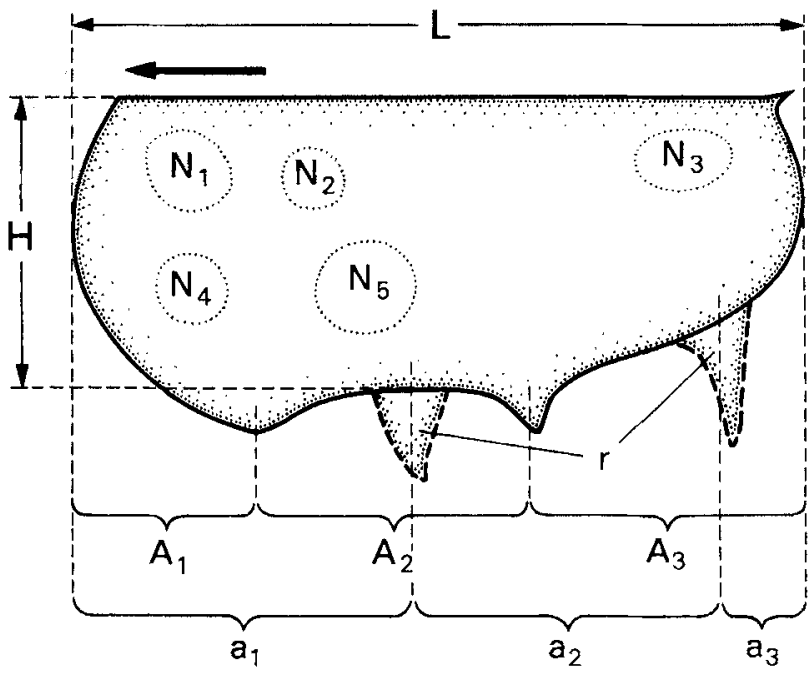

Fig. 4. Gross morphological features of the genus Bidimorpha

Plate 3. Vestrogothia longispinosa Kozur, 1974. 1. Right valve (MB.O. 265), lateral view; l = $2.0 \mathrm{~mm}$. 2. Anterodorsally and posteriorly incomplete right valve (MB.O. 266), lateral view; $1=1.98 \mathrm{~mm}$. 3. Posteriorly incomplete right valve (MB.O. 267), lateral view; $1=1.49 \mathrm{~mm}$. 4. Dorsally incomplete left valve (MB.O. 268), lateral view; $1=1.49 \mathrm{~mm}$. Note distinct $\mathrm{N}_{3} .5$ Incomplete heteromorphic carapace (MB.O. 269), ventral view; $I=1.97 \mathrm{~mm}$. 6. Distorted carapace (MB.O. 270), left lateral view; $l=0.95 \mathrm{~mm}$. 7. Incomplete heteromorphic right valve (MB.O. 256), dorsal view; $1=1.65 \mathrm{~mm}$. 8. Distorted carapace (MB.O. 272), ventral view; distance between ends of spines: $1.05 \mathrm{~mm}$. 9. Two carapaces attached to each other (MB.O. 273), left ventrolateral and right lateral views (a), and right lateral view of smaller carapace (b); $1=0.585 \mathrm{~mm}$ and $\mathrm{l}=0.224 \mathrm{~mm}$, resp. 


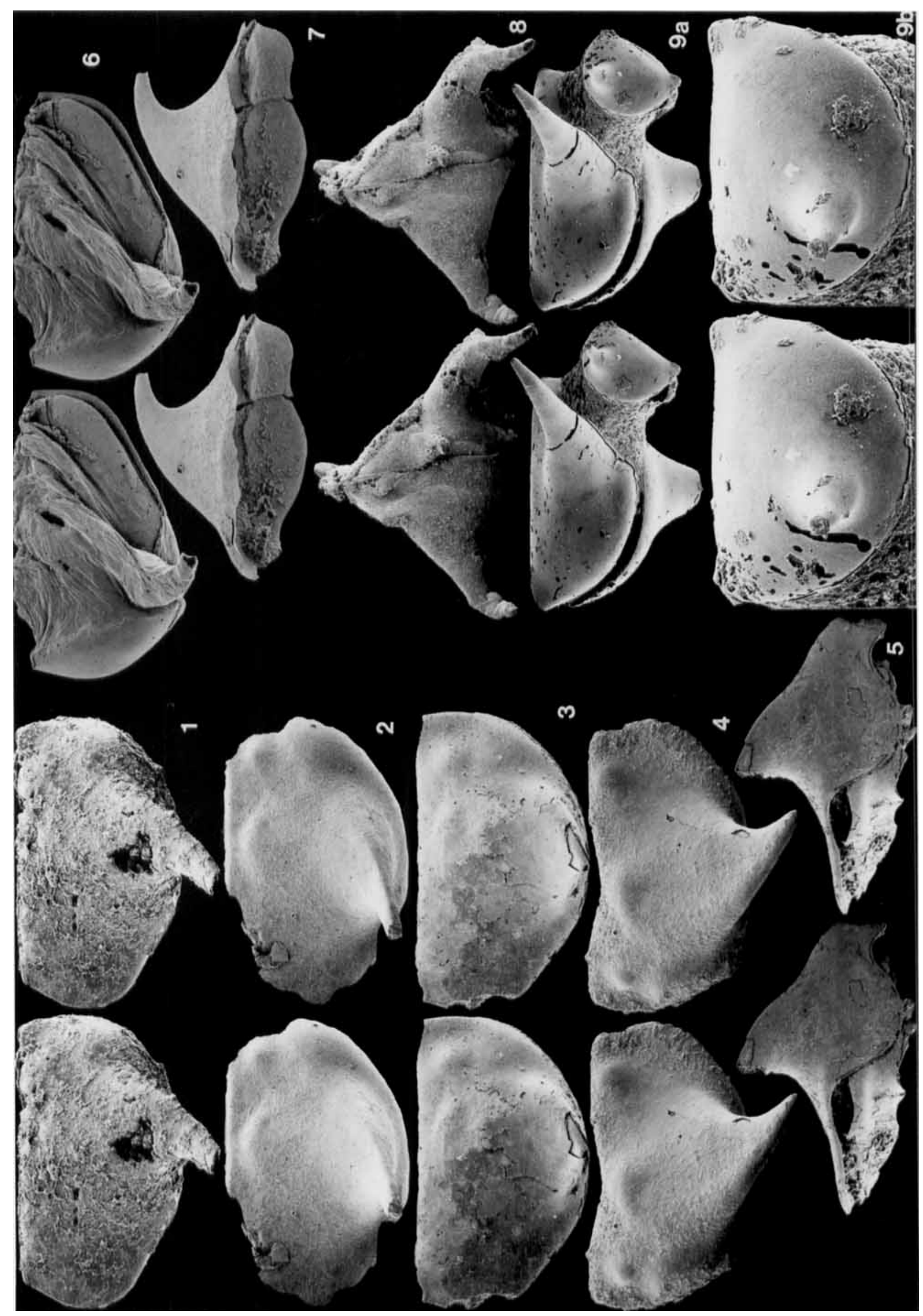


and diverse fauna has led to a more realistic higher taxonomic assignment of the respective genera.

The Subfamily Vestrogothiinae is redefined on the basis of its typical free marginal rim with overlapping and partly interlocking spines and/or lappets. By contrast, the Subfamily Hesslandoninae is characterized by a smooth and evenly developed free marginal rim. In Polyphyma lapworthi (Groom, 1902), the type-species of Cyclotron Rushton, 1969, the precise development of the free margin is insufficiently known. The type material is flattened on the split surface of rock and not well preserved. Also, the revision by Williams et al. (1994) did not bring any new information in this respect. Concerning lobation, Cyclotron is very similar to the vestrogothiine Bidimorpha (Hinz-Schallreuter 1993: Fig. $1 \mathrm{~A}, \mathrm{C})$. For this reason, the Cyclotronidae may be a junior synonym of the Vestrogothiinae, and the genus itself a junior synonym of Vestrogothia or Waldoria.

\section{Genera:}

Bidimorpha Hinz-Schallreuter, 1993

? Cyclotron Rushton, 1969

?Polyphyma Groom, 1902; non Jakovlev, 1877; non Hamm, 1881

?Veldotron Gründel in Gründel \& Buchholz, 1981

Vestrogothia Müller, 1964

?Waldoria Gründel in Gründel \& Buchholz, 1981

Occurrence: Middle to Upper Cambrian; Baltoscandia, England.

\section{Genus Bidimorpha Hinz-Schallreuter, 1993}

Type species: Bidimorpha bidimorpha Hinz-Schallreuter, 1993

Diagn os is: See Hinz-Schallreuter 1993a

Further species:

Bidimorpha arator $\mathrm{n} . \mathrm{sp}$.

Bidimorpha inversa Hinz-Schallreuter, 1993

Bidimorpha labiator $\mathrm{n} . \mathrm{sp}$.

Bidimorpha sexspinosa $\mathrm{n} . \mathrm{sp}$

Occurrence: Middle Cambrian, Baltoscandia.

\section{Bidimorpha arator n. sp.}

Pl. 5, fig. 7; Pl. 6, fig. 6; Pl. 7; Figs 5, 7; Tab. 5

1993c Bidimorpha inversa n. sp. - Hinz-Schallreuter: 400, 410 (partim); Figs $7.4 a-b, 10.1$
Derivation of name: From arator (Latin): plough, after the posterior spine of the right valve which resembles a ploughshare.

Holotype: A ventrally slightly incomplete carapace, MB.O. 298, Pl. 7: 1a-b.

Type locality and type horizon: Same as for Hesslandona abdominalis.

Material: $>50$ carapaces or isolated valves, partly incomplete or fragmentary.

Dimensions and proportions: See Tab. 5.

Diagnosis: Up to at least $2.66 \mathrm{~mm}$ in length. Anterodorsal node $\left(\mathrm{N}_{1}\right)$ of the three anterior nodes strongest and most persistent during ontogeny. $\mathrm{N}_{2}$ and $\mathrm{N}_{4}$ weaker than $\mathrm{N}_{1}$ and $\mathrm{N}_{5} . \mathrm{N}_{5}$ above posterior spine of left valve; distance between $\mathrm{N}_{4}$ and $\mathrm{N}_{5}$ relatively short. In adults and larger larvae, each valve is characterized by two strong ventral spines overlapping the countervalve. The left valve has spines in anteroventral and posterior-centroventral regions, the right valve has spines in the anterior-centroventral
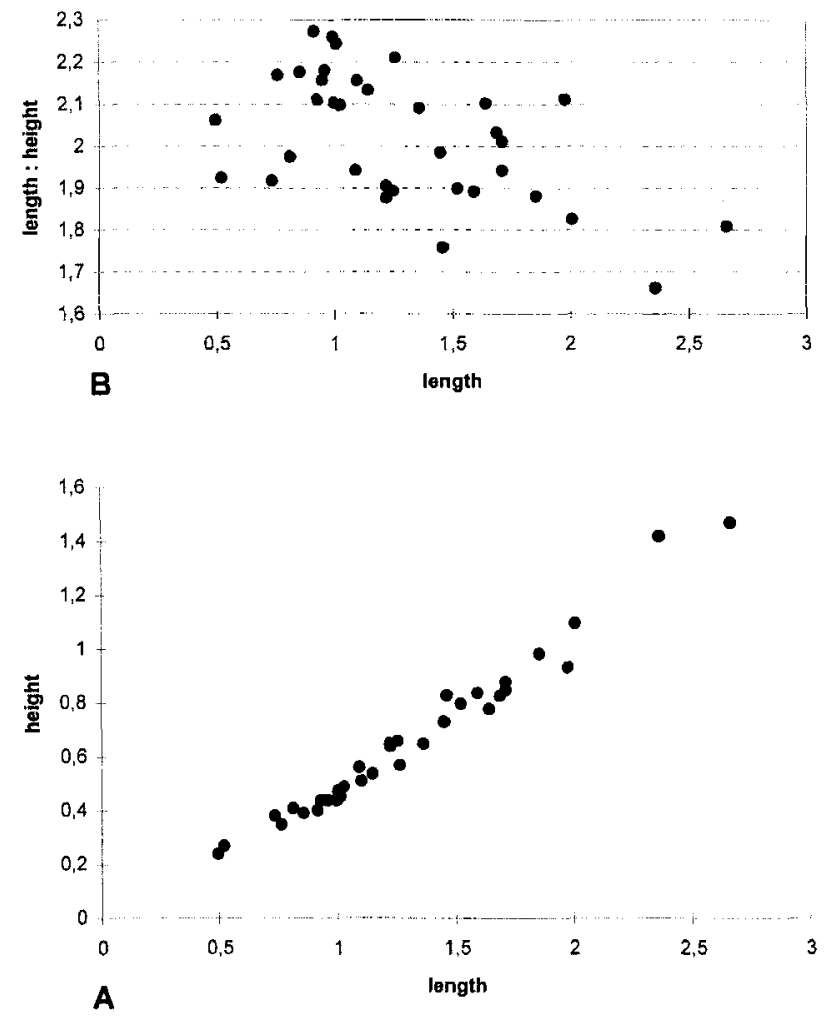

Fig. 5. Ontogeny of Bidimorpha arator. A. length/height diagram, B. gestalt diagram

Plate 4. 1. Vestrogothia herrigi n. sp. Carapace (MB.O. 274), right lateral (a), anterior (b) and ventral views (c); I = $1.26 \mathrm{~mm}$. Note posterior flattening. 2-9. Vestrogothia longispinosa Kozur, 1974. 2. Carapace (MB.O. 275), ventral view; $1=1.04 \mathrm{~mm} .3$. Carapace (MB.O. 276), ventral view; $1=1.05 \mathrm{~mm}$. 4. Carapace of small instar (MB.O. 277 ), dorsal view; $1=0.295 \mathrm{~mm} .5$. Juvenile carapace (MB.O. 278), ventral view; $1=0.4 \mathrm{~mm}$. 6. Juvenile carapace (MB.O. 279); dorsal view; $1=0.69 \mathrm{~mm}$. Interdorsum covered by right valve. Note long acroidal spine. 7. Juvenile carapace (MB.O. 280); ventral view; $1=0.56 \mathrm{~mm} .8$ Juvenile carapace (MB.O. 281); dorsal view; $1=0.445 \mathrm{~mm}$. 9. Juvenile carapace (MB.O. 282); dorsal view; $1=0.46 \mathrm{~mm}$. Note long acroidal spines of interdorsum. 

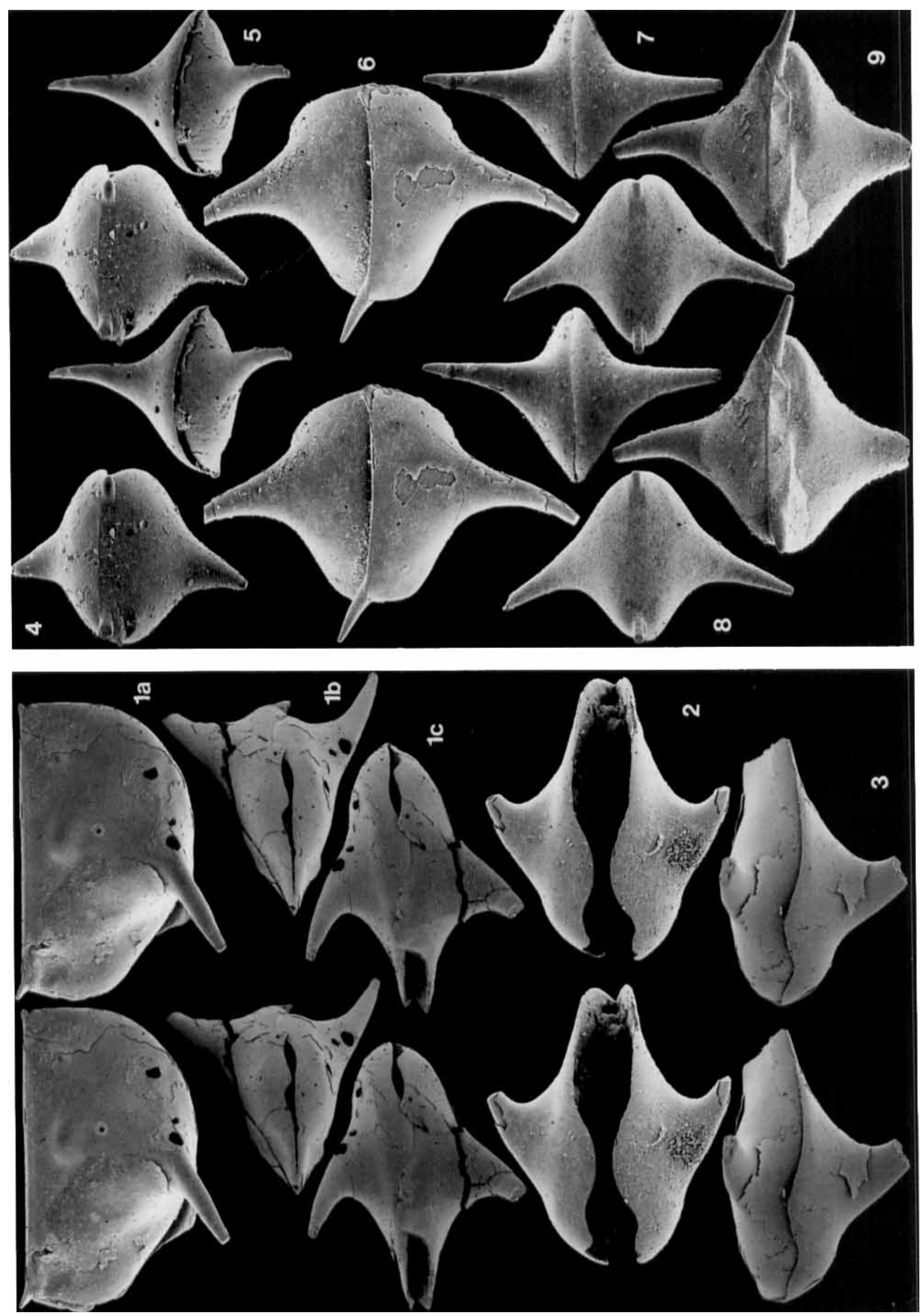

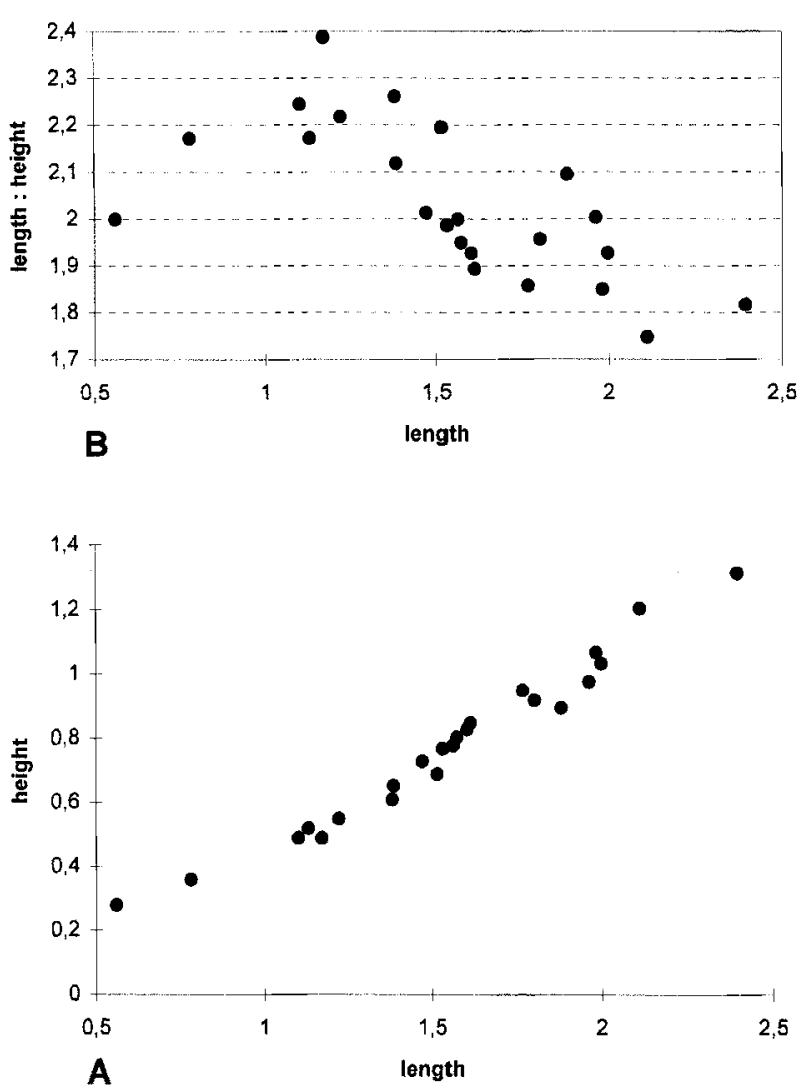

Fig. 6. Ontogeny of Bidimorpha labiator. A. length/height diagram, B. gestalt diagram

and in the posteroventral regions, the latter being at or close to the end of the valve. Distance between the two spines of the right valve relatively large. OTP at about $1 \mathrm{~mm}$.

Description: Largest measured carapace $2.66 \mathrm{~mm}$ long. Gestalt in most cases moderately to very long. Outline preplete. Dorsal margin long and straight with cardinal angles of about the same size, around $90^{\circ}$ (Pl. 7: 4a). Interdorsum moderately broad, being broadest anteriorly above the $\mathrm{N}_{1}$ and tapering more or less continuously towards the posterior side. At both ends it may pass into small acroidal spines. Valves moderately convex, having the anterior part more inflated than the posterior one. Lobation consists of five node-like lobes. Four of these are located on the inflated anterior part of the valve that roughly resembles a somewhat irregular rectangle. $N_{1}$ and $N_{2}$ are situated close to each other

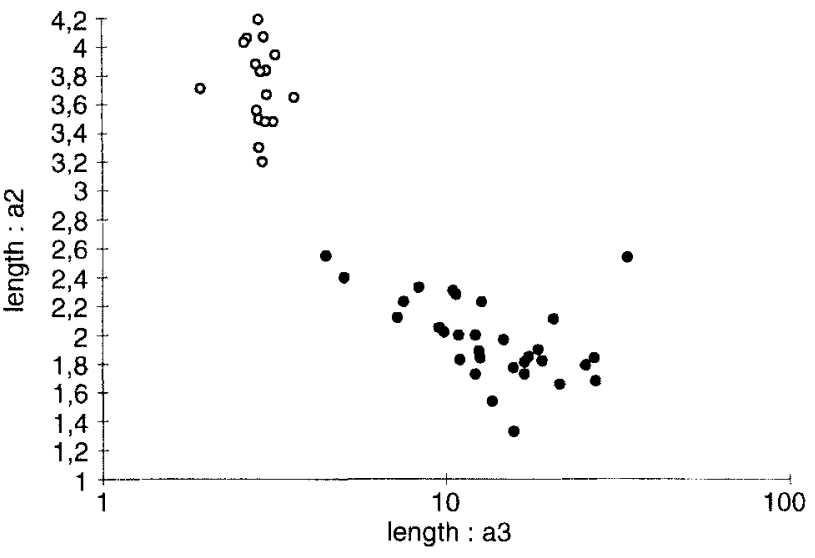

Fig. 7. Relative distance between ventral spincs and between posteroventral spine and posterior end

and near dorsal margin. The other two lobes of the quadrangle, $\mathrm{N}_{4}$ and $\mathrm{N}_{5}$, are ventrally located in a slightly more posterior position than $\mathrm{N}_{1}$ and $N_{2}$, and not as close to each other as $N_{1}$ and $N_{2}$. $\mathrm{N}_{5}$ occurs above the posterior spine of the left valve on a transversal axis through the spine or slightly in front of it (Pl.7: 1a, 2a). Of all nodes, $\mathrm{N}_{1}$ is the strongest and most persistent one, while $\mathrm{N}_{4}$ is the weakest developed element. $\mathrm{N}_{3}$ is an additional subdorsal node that occurs in the anterior part of the posterodorsal region.

Anterior and posterior ends of valves may be slightly flattened (Pl. 7: 1a, 3). Free marginal rim differentiated into two ventral spines in each valve that distinctly interlock in the closed carapace condition. Spines of the left valve occur at the vertical levels of $\mathrm{N}_{1}$ and $\mathrm{N}_{5}$; spines of the right valve are positioned at the level of $\mathrm{N}_{2}$ and at the posterior end of the valve. Spines are ventrally directed and somewhat bent towards the counter-valve. Outer surface smooth.

Ontogeny: Both lobation and ventral spines gradually evolve during ontogeny. The smallest larvae lack spines and distinct nodes, except for the already indicated $\mathrm{N}_{1}$ (Pl. 7: 5). Subsequent, but still small instars (Pl. 7: 4a, b; $1=0.52 \mathrm{~mm}$ ) lack ventral nodes, but have already one strong ventral spine developed in each valve: it is the posterior one in the right valve that is posteriorly directed and the spine in the posterior part

Plate 5. 1-6. Vestrogothia longispinosa Kozur, 1974. 1. Carapace (MB.O. 283), right lateral (a) and ventral views (b); $1=1.06$ $\mathrm{mm}$. 2. Carapace (MB.O. 284), ventral view; $1=0.98 \mathrm{~mm}$. 3. Carapace (MB.O. 285), ventral view; $1=0.76 \mathrm{~mm}$. 4. Incomplete carapace, dorsal view; $1=1.55 \mathrm{~mm}$ (specimen lost). 5. Posteriorly incomplete left valve (MB.O. 286), lateral view; $1=1.57$ mm. Note anteroventral 'corner' just in front of spine. 6. Right valve (MB.O. 287), lateral view; $1=1.53 \mathrm{~mm}$. Note distinct $\mathrm{N}_{2}$. 7. Bidimorpha arator $\mathrm{n}$. $\mathrm{sp}$. Anteriorly incomplete carapace (MB.O. 288), right lateral view; $\mathrm{l}=1.25 \mathrm{~mm}$. A variety with great distance between posteriormost spine and the posterior end of the carapace. 8. Bidimorpha sexspinosa n. sp. Holotype, carapace (MB.O. 289), left lateral (a), dorsal (b) and ventral views (c); $I=1.59 \mathrm{~mm}$. Note development of six ventral spines. 


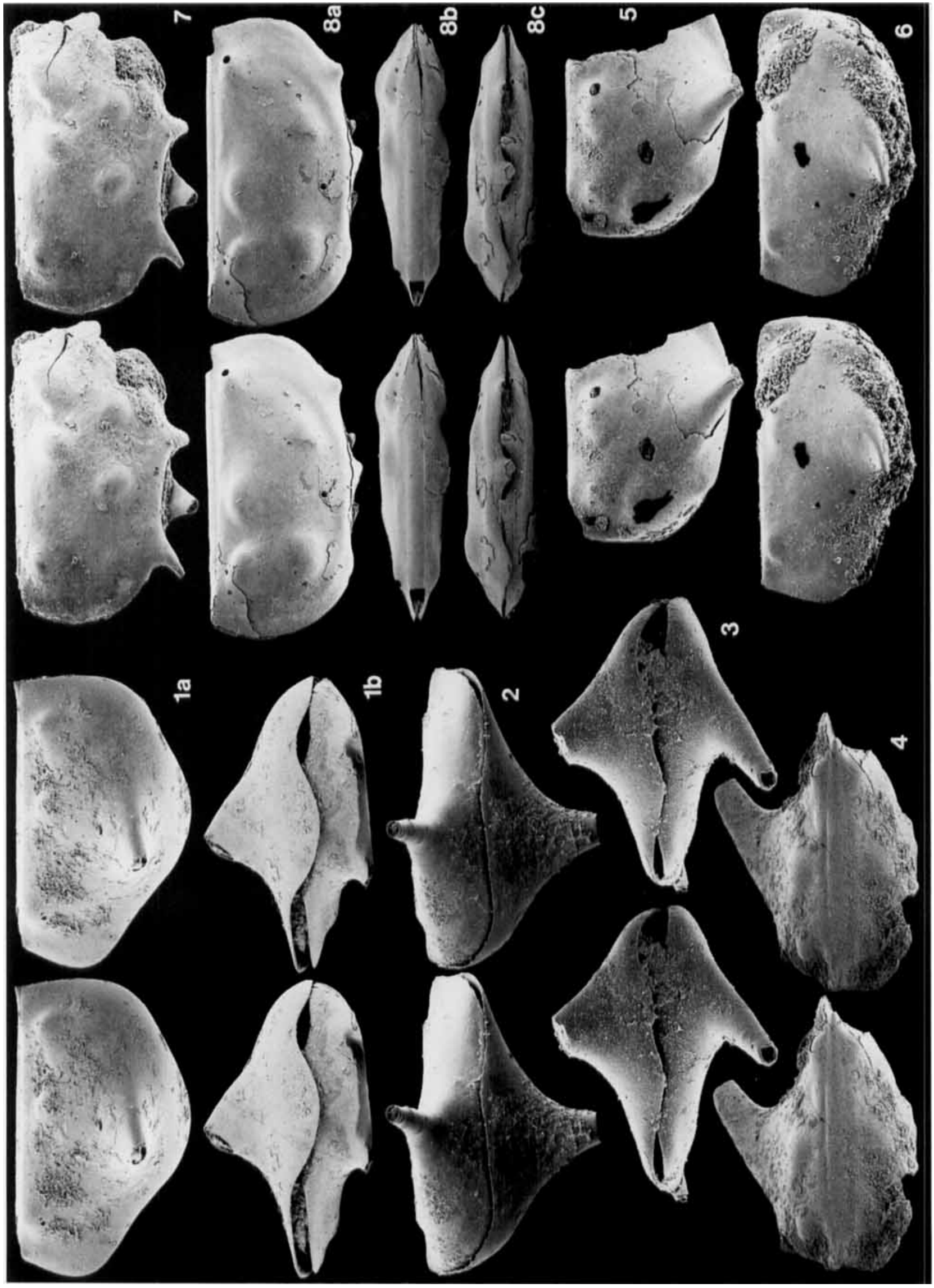


Table 5

Dimensions and proportions of Bidimorpha arator.

\begin{tabular}{llllll}
\hline Cat. no. & Specimen & Pl.: Fig. & $\begin{array}{l}\mathrm{L} \\
(\mathrm{mm})\end{array}$ & $\begin{array}{l}\mathrm{H} \\
(\mathrm{mm})\end{array}$ & $\mathrm{L}: \mathrm{H}$ \\
\hline 297 & $\begin{array}{l}\text { carapace } \\
\text { paratype }\end{array}$ & $6: 8$ & 1.98 & 0.94 & 2.11 \\
298 & $\begin{array}{l}\text { carapace } \\
\text { holotype } \\
288\end{array}$ & $7: 1$ & 1.59 & 0.84 & 1.89 \\
300 & $\begin{array}{l}\text { carapace } \\
\text { paratype } \\
\text { carapace }\end{array}$ & $5: 7$ & 1.25 & 0.66 & 1.89 \\
299 & $\begin{array}{l}\text { paratype } \\
\text { carapace } \\
\text { paratype }\end{array}$ & $7: 2$ & 1.14 & 0.54 & 2.13 \\
303 & $\begin{array}{l}\text { carapace } \\
\text { paratype } \\
301\end{array}$ & $7: 6$ & 1.10 & 0.51 & 2.16 \\
302 & $\begin{array}{l}\text { carapace } \\
\text { paratype } \\
\text { carapace } \\
\text { paratype }\end{array}$ & $7: 4$ & 1.01 & 0.45 & 2.24 \\
& & 0.52 & 0.27 & 1.93 \\
\end{tabular}

of the centroventral region of the left valve. The anterior (centroventral) spine of the right valve is only indicated and resembles a small lappet more than a proper spine. In medium-sized ontogenetic stages $(\mathrm{Pl} .7: 6 \mathrm{a}-\mathrm{c} ; 1=1.10 \mathrm{~mm})$, ventral nodes as well as three strong ventral spines are developed: the centroventral spine of the right valve is as strong as the other two spines, and the posterior spine of the right valve becomes more ventrally directed. The OTP of $B$. arator occurs at about $1 \mathrm{~mm}$ (Fig. 5B). Interdorsal or acroidal spines are more prominent in young instars (Pl. 7: 4a, 5), with the posterior spine of the right valve being posteriorly directed (Pl. 7: 5, 6a).

Comparison: B. arator differs from B. labiator mainly in the relative distance between the two ventral spines of the right valve of larger instars. The posterior spine close to the posterior end is most characteristic for B. arator. There are differences also in the development of the four anterior nodes. $\mathrm{N}_{1}$ is the strongest node in $B$. arator, whereas B. labiator has both $\mathrm{N}_{2}$ and $\mathrm{N}_{4}$ better developed than $\mathrm{N}_{1}$ and $\mathrm{N}_{5}$. Furthermore, $\mathrm{N}_{5}$ is more posteriorly located in $B$. labiator.

The possibility that both taxa are dimorphs of the same species can be excluded by the appearance of the diagnostic characters already in very small instars of about $0.5 \mathrm{~mm}$ in length. In the dimorphic $B$. bidimorpha, sex differentiation starts at a size of about $1 \mathrm{~mm}$ in length (HinzSchallreuter 1993a: Fig. 6). Furthermore, despite the great variation in spinosity, both species are distinctly separated by their typical position of the spines (Fig. 7).

Remarks: The carapace (AGH 128-4) from a geschiebe of Gislövshammar was described as a juvenile tecnomorph and paratype of Bidimorpha inversa (Hinz-Schallreuter 1993c: 400, 401). Since the specimen is very similar to the carapace figured on Pl. 7: $5 \mathrm{a}, \mathrm{b}$, it is assigned to $B$. arator.

\section{Bidimorpha labiator $\mathbf{n}$. sp.}

Pl. 6, figs 1-7; Pl. 8, figs 2-3; Pl. 10, fig. 3; Figs 6, 7; Tab. 6

Holotype: Carapace, MB.O. 290, Pl. 6: 1a-c.

Type locality and type horizon: Same as for Hesslandona abdominalis.

Material: $>50$ carapaces or isolated valves, partly incomplete or fragmentary.

Dimensions and proportions: See Tab. 6.

Diagnosis: Up to at least $2.39 \mathrm{~mm}$ long. $\mathrm{N}_{1}$ and $\mathrm{N}_{5}$ weaker than $\mathrm{N}_{2}$ and $\mathrm{N}_{4}$. Distance between $\mathrm{N}_{4}$ and $\mathrm{N}_{5}$ relatively large. $\mathrm{N}_{4}$ slightly behind posterior spine of left valve. Each valve of adults and larger larvae have two strong ventral

Table 6

Dimensions and proportions of Bidimorpha labiator.

\begin{tabular}{llllll}
\hline Cat. no. & Specimen & Pl.: Fig. & $\begin{array}{l}\mathrm{L} \\
(\mathrm{mm})\end{array}$ & $\begin{array}{l}\mathrm{H} \\
(\mathrm{mm})\end{array}$ & $\mathrm{L}: \mathrm{H}$ \\
\hline 295 & $\begin{array}{l}\text { carapace } \\
\text { paratype }\end{array}$ & $6: 6$ & 0.78 & 0.36 & 2.17 \\
294 & $\begin{array}{l}\text { carapace } \\
\text { paratype }\end{array}$ & $6: 5$ & 1.17 & 0.49 & 2.39 \\
293 & $\begin{array}{l}\text { carapace } \\
\text { paratype }\end{array}$ & $6: 4$ & 1.38 & 0.61 & 2.62 \\
296 & $\begin{array}{l}\text { carapace } \\
\text { paratype }\end{array}$ & $6: 7$ & 1.56 & 0.78 & 2.0 \\
327 & $\begin{array}{l}\text { carapace } \\
\text { paratype }\end{array}$ & $10: 3$ & 1.66 & 0.90 & 1.84 \\
292 & $\begin{array}{l}\text { LV } \\
\text { paratype }\end{array}$ & $6: 3$ & 1.61 & 0.85 & 1.89 \\
291 & $\begin{array}{l}\text { carapace } \\
\text { paratype } \\
\text { carapace } \\
\text { holotype }\end{array}$ & $6: 2$ & 1.96 & 0.98 & 2.0 \\
& $6: 1$ & 2.39 & 1.32 & 1.82 \\
\hline
\end{tabular}

Plate 6. 1-7. Bidimorpha labiator n. sp. 1. Holotype, carapace (MB.O. 290), left lateral (a), dorsal (b) and ventral views (c); $1=2.39 \mathrm{~mm}$. 2. Paratype, carapace (MB.O. 291), right lateral (a), ventral (b) and dorsal views (c); $1=1.96 \mathrm{~mm}$. 3. Paratype, laterally incomplete carapace (MB.O. 292), right lateral view; $1=1.61 \mathrm{~mm}$. 4. Paratype, carapace (MB.O. 293), right lateral view; $1=1.38 \mathrm{~mm}$. 5. Paratype, carapace (MB.O. 294), left lateral view; $I=1.17 \mathrm{~mm}$. 6. Paratype, carapace (MB.O. 295), left lateral view; $1=0.78 \mathrm{~mm}$. 7. Paratype, carapace (MB. 296), ventral view; $1=1.56 \mathrm{~mm}$. 8. Bidimorpha arator n. sp. Paratype, incomplete carapace (MB.O. 297), ventral view; $1=1.98 \mathrm{~mm}$. 

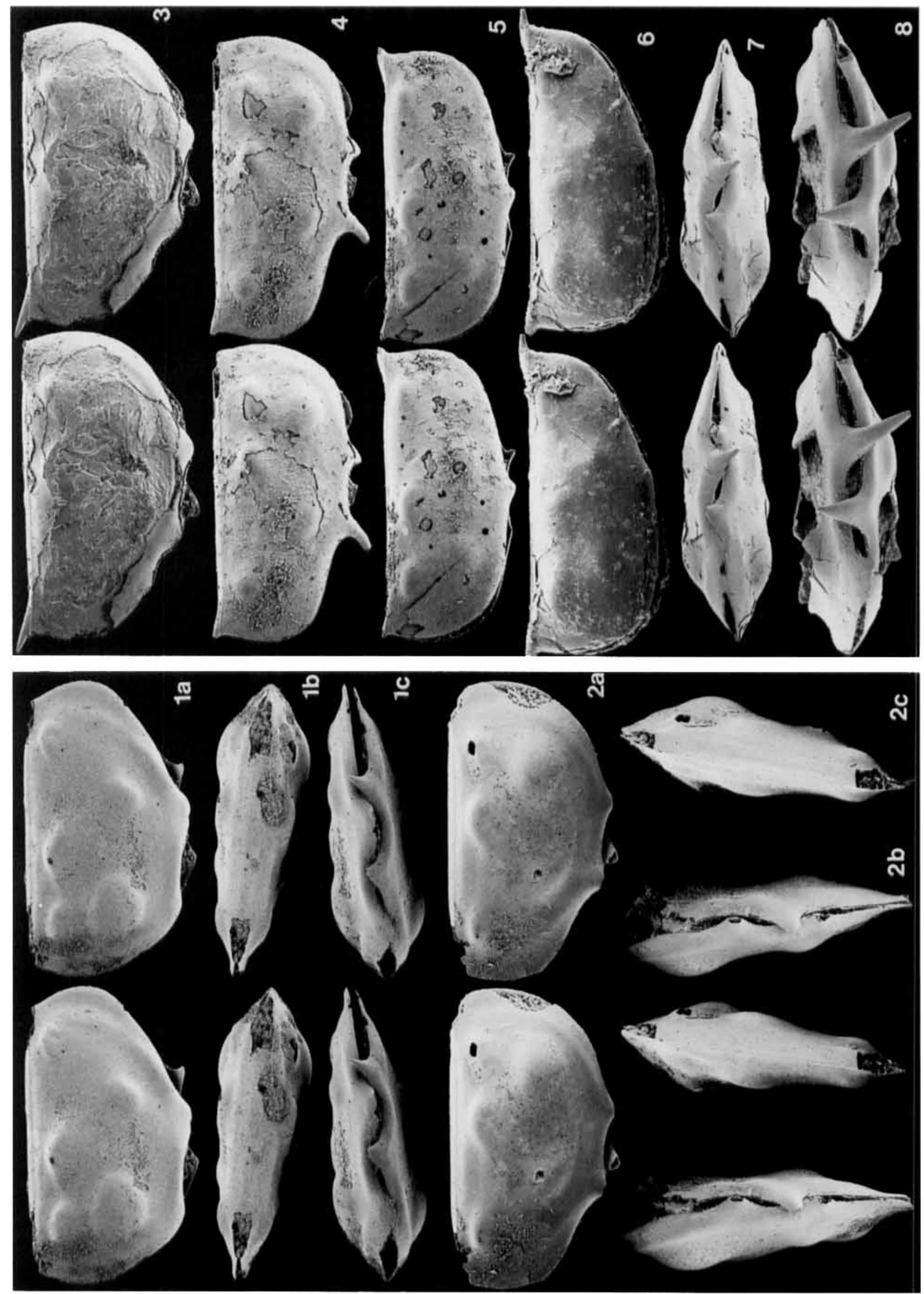
spines: in the anteroventral and centroventral regions of the left valve, and in both the anteriorcentroventral and posterior-centroventral regions of the right valve. The posterior spine in the right valve is distinctly distant from the posterior end of the valve. Distance between the two spines of the right valve relatively short; distance of the posterior spine to the posterior end large. Spines strongly bent towards counter-valve.

Description: Largest measured valve 2.39 $\mathrm{mm}$ long. Gestalt mostly moderately to very long. Outline preplete. Dorsal margin long and straight. Cardinal angles in most cases slightly exceeding $90^{\circ}$; rarely are they about or even less than $90^{\circ}$. Both cardinal angles may be equal in size. Interdorsum moderately broad, being broadest anteriorly in the transversal axis of $N_{1}$ and tapering only slightly towards the posterior end. In both directions, it passes into small acroidal spines of which the anterior one may be sligthly more raised. Valves moderately convex with the anterior portion more inflated than the posterior part. On the inflated anterior portion, there are four nodes arranged in an oblique quadrangle: $\mathrm{N}_{1}$ and $\mathrm{N}_{2}$ occur close together and near dorsal margin. Two further nodes, $\mathrm{N}_{4}$ and $\mathrm{N}_{5}$, are ventrally located in a slightly more posterior position than the former nodes and not as closely spaced. $\mathrm{N}_{5}$ is situated behind the transversal axis that extends through the center of the posterior spine of the left valve. $\mathrm{N}_{2}$ and $\mathrm{N}_{4}$ are more pronounced than $\mathrm{N}_{1}$ and $\mathrm{N}_{5} . \mathrm{N}_{3}$ is another subdorsal node in the anterior part of the posterodorsal field. Anterior and posterior ends of valves may be slightly flattened (Pl. 6: 1a, 2a). Ventral margin of each valve carries two ventral spines. The spines of the left valve are located on the transversal axes of $N_{1} / N_{4}$, and of the anterior end of $\mathrm{N}_{5}$. The spines of the right valve occur along the transversal axes of $\mathrm{N}_{2}$ and at the posterior end of $\mathrm{N}_{5}$. The spines are ventrally directed and strongly bent towards the countervalve. In the closed carapace position they form some sort of interlocking clausal sculptures. Outer surface smooth.

Ontogeny: According to Fig. $6 \mathrm{~B}$ the gestalt of specimens $>1.1 \mathrm{~mm}$ becomes continuously higher while the two smallest specimens of less than $0.9 \mathrm{~mm}$ reflect the tendency of an increasingly longer gestalt during early ontogeny. However, the material is too insufficient for a specification of the OTP. The smallest larvae seem to lack both lobation and ventral spines. Therefore, their distinction from equally-sized larvae of other species is hardly possible. In subsequent larval stages, lobation and ventral spines gradually develop (Pl. 6: 5-6).

Comparison: B. inversa Hinz-Schallreuter, 1993 differs from B. labiator mainly in the considerably larger $\mathrm{N}_{3}$ (Hinz-Schallreuter 1993c: Fig. 7.3). Differences between B. labiator and B. arator are outlined in the description of the latter species.

\section{Bidimorpha sexspinosa n. sp.}

Pl. 5, fig. 8a-c; Tab. 7

Derivation of name: According to the six spines at the ventral free margin of the carapace.

Holotype: Carapace, MB.O.289, P1. 5: $8 \mathrm{a}-\mathrm{c}$.

Type locality and type horizon: Same as for Hesslandona abdominalis.

Material: 1 complete (holotype) and 1 fragmentary carapace.

Dimensions and proportions: See Tab. 7.

Diagnosis: Up to at least $2.00 \mathrm{~mm}$. Besides the four alternating ventral spines, two further spines in the posteroventral regions of the carapace face each other.

Description: A carapace very similar to $B$. labiator with regard to nodes and ventral spines. However, apart from the four antero- and centroventral spines, another pair of spines occurs in the posteroventral region (Pl. 5: 8a-c). While the anterior spines are arranged in alternating positions as in typical $B$. labiator specimens, the

Table 7

Dimensions and proportions of Bidimorpha sexspinosa n. sp.

\begin{tabular}{llllll}
\hline Cat. no. & Specimen & Pl.: Fig. & $\begin{array}{l}\mathrm{L} \\
(\mathrm{mm})\end{array}$ & $\begin{array}{l}\mathrm{H} \\
(\mathrm{mm})\end{array}$ & L:H \\
\hline 289 & $\begin{array}{l}\text { carapace } \\
\text { holotype } \\
320\end{array}$ & $5: 8 \mathrm{a}-\mathrm{c}$ & 1.59 & 0.74 & 2.15 \\
& $\begin{array}{l}\text { carapace } \\
\text { paratype }\end{array}$ & unfig. & 2.0 & 0.98 & 2.04 \\
\hline
\end{tabular}

Plate 7. Bidimorpha arator n. sp. 1. Holotype, posteroventrally slightly incomplete carapace (MB.O. 298), left lateral (a) and ventral views (b); $1=1.59 \mathrm{~mm}$. 2. Paratype, anteriorly incomplete carapace (MB.O. 299), right lateral (a) and ventral (b) view; $1=1.14 \mathrm{~mm}$. 3. Paratype, carapace (MB.O. 300), left lateral view; $1=1.22 \mathrm{~mm}$. 4. Paratype, carapace (MB.O. 301), left lateral (a) and ventral views; $l=1.01 \mathrm{~mm}$. 5. Paratype, carapace (MB.O. 302), right lateral view; $1=0.52 \mathrm{~mm}$. 6. Paratype, carapace (MB.O. 303), right lateral (a), dorsal (b; anterior: left) and ventral views (c; anterior: right); $1=1.10 \mathrm{~mm}$. 

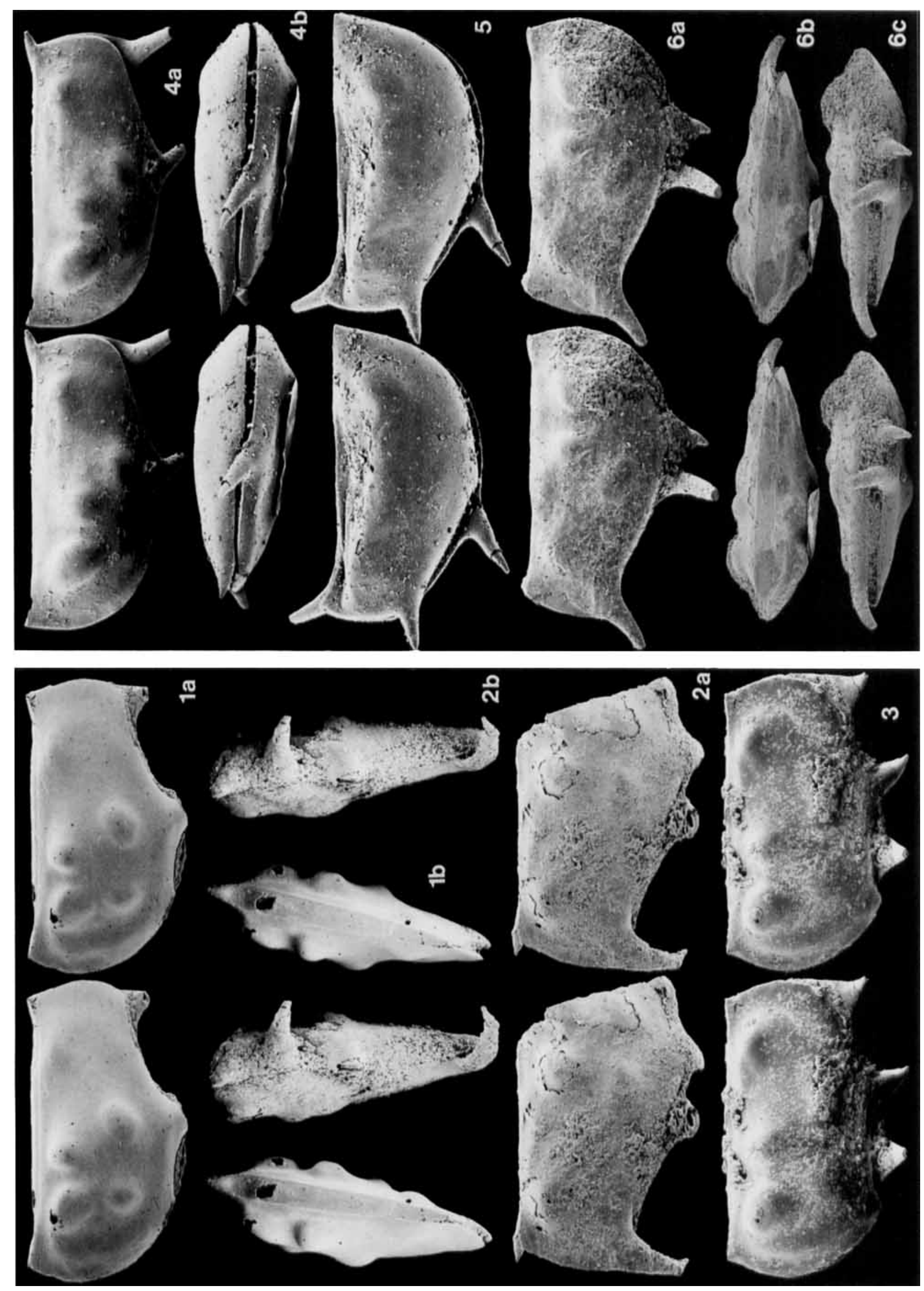
two posterior spines occur facing each other. It also differs in the greater relative distance between the spines of the right valve.

Genus Vestrogothia Müller, 1964

Type species: Vestrogothia spinata Müller, 1964.

Diagnosis: See Hinz-Schallreuter 1993c: 403.

Further species: 1.c.

Remarks: 1. c.

Occurrence: Middle and Upper Cambrian; Baltoscandia, Canada, England.

\section{Vestrogothia herrigi n. sp.}

Pl. 4, figs 1a-c; Pl. 8, figs 6-8; Tab. 8

Derivation of name: In honour of Ekkehard Herrig, Greifswald

Holotype: Carapace, MB.O. 323, Pl. 8: 6

Type locality and type horizon: Same as for Hesslandona abdominalis.

Material: 4 carapaces and isolated valves.

Dimensions and proportions: See Tab. 8.

Diagnosis: Length up to at least $1.61 \mathrm{~mm}$. L/R- or R/L-overlap. Strong ventrolateral spine. Free margin of larger valve forms a posteroventral spine-like protuberance.

Remarks: This species is characterized by the spine-like posteroventral protuberance of the free margin which is distinct from $V$. longispinosa. A similar process occurs also in Cyclotron ventrospinata where it is developed at least on the left valve. The latter species, however, lacks a ventrolateral spine.

Table 8

Dimensions and proportions of Vestrogpthia herrigi $\mathrm{n} . \mathrm{sp}$.

\begin{tabular}{|c|c|c|c|c|c|}
\hline Cat. no. & Specimen & Pl.: Fig. & $\begin{array}{l}\mathrm{L} \\
(\mathrm{mm})\end{array}$ & $\begin{array}{l}\mathrm{H} \\
(\mathrm{mm})\end{array}$ & $\mathrm{L}: \mathrm{H}$ \\
\hline 323 & $\begin{array}{l}\text { carapace } \\
\text { holotype }\end{array}$ & $8: 6$ & 1.61 & 0.86 & 1.86 \\
\hline 307 & $\begin{array}{l}\text { carapace } \\
\text { paratype }\end{array}$ & $8: 7$ & 1.27 & 0.66 & 1.91 \\
\hline 322 & $\begin{array}{l}\text { RV } \\
\text { paratype }\end{array}$ & $8: 8$ & 1.27 & 0.65 & 1.95 \\
\hline 274 & $\begin{array}{l}\text { carapace } \\
\text { paratype }\end{array}$ & $4: 1$ & 1.26 & 0.74 & 1.70 \\
\hline
\end{tabular}

As in $V$. longispinosa, the holotype of $V$. herrigi shows $\mathrm{R} / \mathrm{L}$-overlap. It is unclear, yet whether carapaces and valves that clearly document a reversal of overlap (Pl. 4: 1a-c, ?Pl. 8: $7 b)$ belong to $V$. herrigi or perhaps to another species. In this paper they are tentatively referred to $V$. herrigi.

Vestrogothia longispinosa Kozur, 1974

Pl. 1, figs 3-7; Pl. 3; Pl. 4, figs 2-9; Pl. 5, figs 1-6; PI. 8, fig. 4; PI. 9, figs 1, 2, 4; Fig. 8; Tab. 9

1993a Vestrogothia longispinosa Kozur, 1974 - Hinz-Schallreuter: 403; Figs $8.1-3$ (q. v. further synonymy)

1994 Vestrogothia longispinosa Kozur -- Williams, Siveter, Berg-Madsen \& Hinz-Schallreuter: 21-26, pls. 21, 22 and 21, 24 , figs $1-2$

Holotype: Juvenile left valve no. XXVI/1, Staatliche Museen Schloß Elisabethenburg Meiningen (?) - Kozur 1974: Fig. 1.

Material: $>1500$ carapaces and isolated valves.

Dimensions and proportions: See Tab. 9.

Table 9

Dimensions and proportions of Vestrogothia longispinosa Kozur, 1974.

\begin{tabular}{lllllr}
\hline Cat. no. & Specimen & Pl.: Fig. & $\begin{array}{l}\text { L } \\
(\mathrm{mm})\end{array}$ & $\begin{array}{l}\text { H } \\
(\mathrm{mm})\end{array}$ & L:H \\
\hline 319 & carapace & unfig. & 2.02 & 1.26 & 1.61 \\
265 & RV & $3: 1$ & 2.0 & 1.14 & 1.75 \\
266 & RV & $3: 2$ & $>1.99$ & 1.30 & $>1.53$ \\
318 & carapace & unfig. & 1.94 & 1.23 & 1.58 \\
316 & carapace & unfig. & 1.87 & 1.18 & 1.58 \\
317 & carapace & unfig. & 1.78 & 1.03 & 1.74 \\
286 & LV & $5: 5$ & 1.57 & 1.18 & $?$ \\
308 & RV & $8: 5$ & 1.56 & 0.93 & 1.68 \\
287 & RV & $5: 6$ & 1.53 & 0.81 & 1.89 \\
268 & LV & $3: 4$ & 1.49 & 0.81 & 1.83 \\
267 & RV & $3: 3$ & 1.49 & 0.88 & 1.70 \\
257 & carapace & $1: 7$ & 1.24 & 0.71 & 1.75 \\
283 & carapace & $5: 1$ & 1.06 & 0.63 & 1.69 \\
275 & carapace & $4: 2$ & 1.04 & 0.58 & 1.79 \\
284 & carapace & $5: 2$ & 0.98 & 0.52 & 1.88 \\
285 & carapace & $5: 3$ & 0.76 & 0.41 & 1.84 \\
279 & carapace & $4: 6$ & 0.69 & 0.38 & 1.83 \\
$273 \mathrm{a}$ & carapace & $3: 9$ & 0.59 & 0.33 & 1.77 \\
280 & carapace & $4: 7$ & 0.56 & 0.32 & 1.77 \\
282 & carapace & $4: 9$ & 0.46 & 0.29 & 1.60 \\
281 & carapace & $4: 8$ & 0.45 & 0.29 & 1.54 \\
278 & carapace & $4: 5$ & 0.4 & 0.26 & 1.56 \\
277 & carapace & $4: 4$ & 0.295 & 0.22 & 1.35 \\
2736 & carapace & $3: 9$ & 0.22 & 0.17 & 1.31
\end{tabular}

Plate 8. 1. Falites insula n. sp. Paratype, left valve (MB.O. 304), interior view; $1=0.68 \mathrm{~mm}$. Note nearly complete doublure 2-3. Bidimorpha labiator n. sp. 2. Incomplete carapace (MB.O. 310), dorsal view; length of interdorsum $1.74 \mathrm{~mm}$. Note small dorsa on both sides of the interdorsum. 3. Agglomerate of small juveniles (MB.O. 305); length of valve with centroventral spine (interior view of valve in center of agglomerate): $0.56 \mathrm{~mm}$. 4. Vestrogothia longispinosa Kozur,1974. Agglomerate of small juveniles (MB.O. 306); l = $2.63 \mathrm{~mm}$. 5. Vestrogothia minilaterospinata n. sp., holotype (MB.O. 321), carapace left lateral (a) and ventral (b: anterior to the left) views; $1=1.34 \mathrm{~mm}$. 6-8. Vestrogothia herrigi $\mathrm{n}$. sp. 6. Holotype (MB.O. 323), incomplete carapace, ventral (a: anterior to the right) and right lateral (b) views; $1=1.61 \mathrm{~mm}$. 7. Paratype (MB.O. 3(1)7), incomplete carapace, left lateral (a) and ventral (b: anterior to the left) views; $l=1.27 \mathrm{~mm}$. 8. Paratype (MB.O. 322), right valve, interior view; $1=1.27 \mathrm{~mm}$. Note inflated inner lamella or demineralized left valve. 

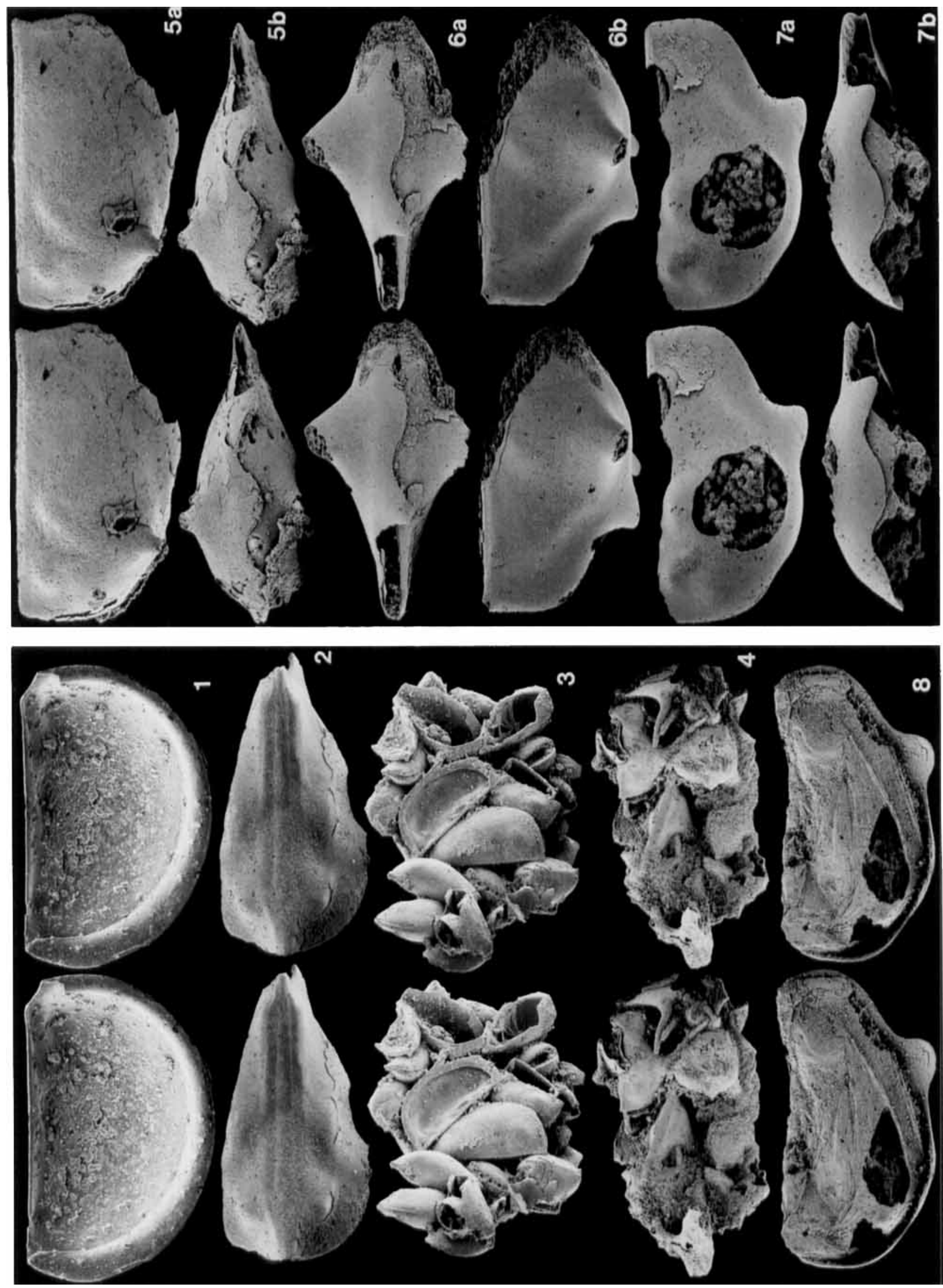

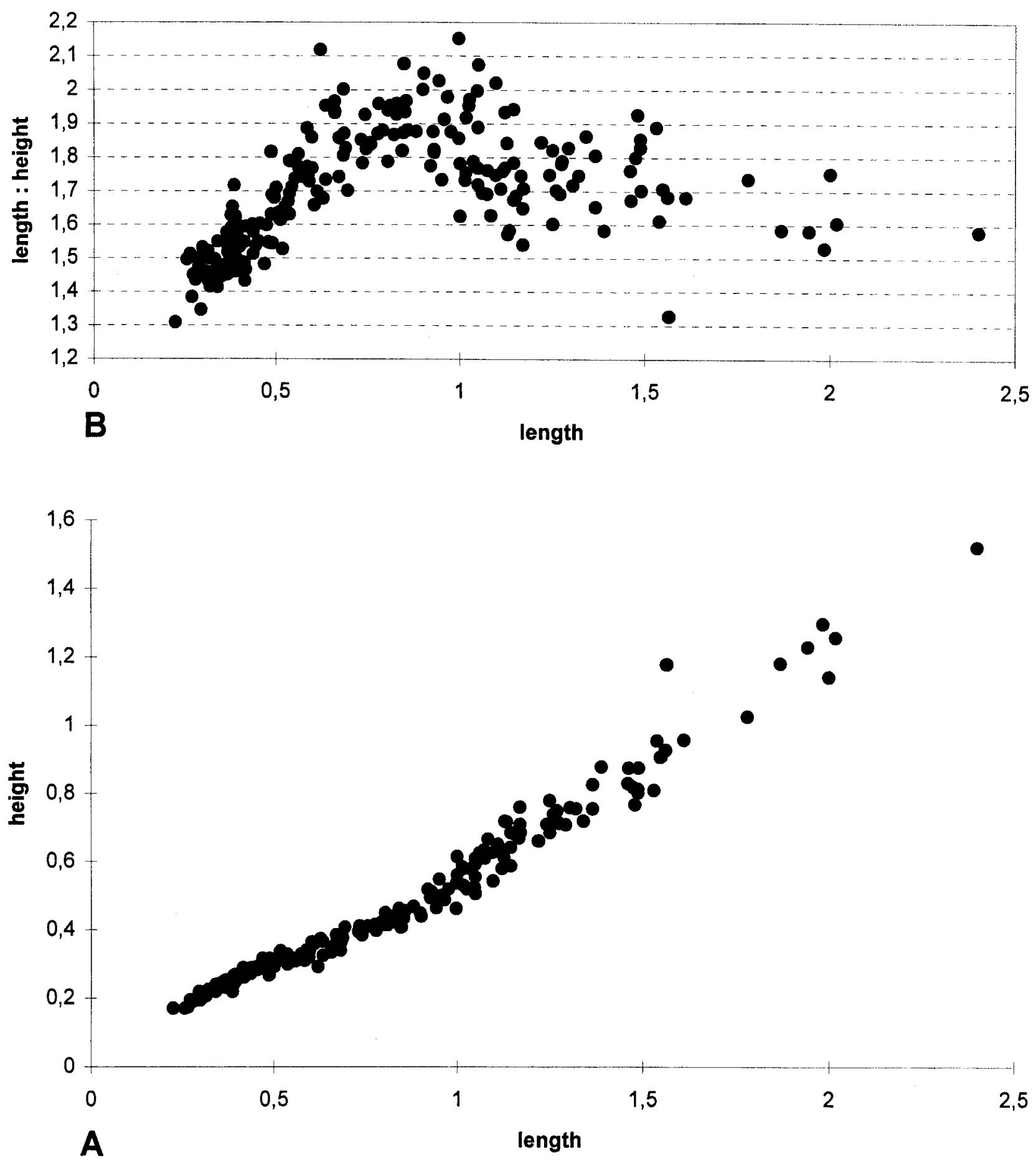

Fig. 8. Ontogeny of Vestrogothia longispinosa. A. length/height diagram, B. gestalt diagram

Plate 9. Borings in ostracod shells. 1-3. Tube-like borings parallel to the outer or inner surface of the shells. 1-2. Vestrogothia longispinosa Kozur, 1974. 1. Posteriorly incomplete right valve (MB.O. 324) with borings on the interior side, interior view (a) and details $(\mathrm{b}-\mathrm{c}) ; 1=1.27 \mathrm{~mm}$. 2. Posteriorly incomplete left valve (MB.O. 325) with borings on the outer side (arrow), lateral view (a) and details (b); $h=1.74 \mathrm{~mm}$. 3. Hesslandona abdominalis $n$. sp., juvenile carapace (MB.O. 309), right lateral view (a); $\mathbf{l}=0.38 \mathrm{~mm}$. Note borings in anterodorsal (b) and posteroventral region (c). 4. Paired borings perpendicular to the shell surface in Vestrogothia longispinosa Kozur, 1974. Anterodorsally incomplete right valve (MB.O. 308), lateral (a) and ventral views (b); $1=1.56 \mathrm{~mm} ; \mathrm{c}-\mathrm{d}$ : details of lateral surface, x 270 and x 640, resp. Note posterior flattening and distinct $\mathrm{N}_{3}$. 

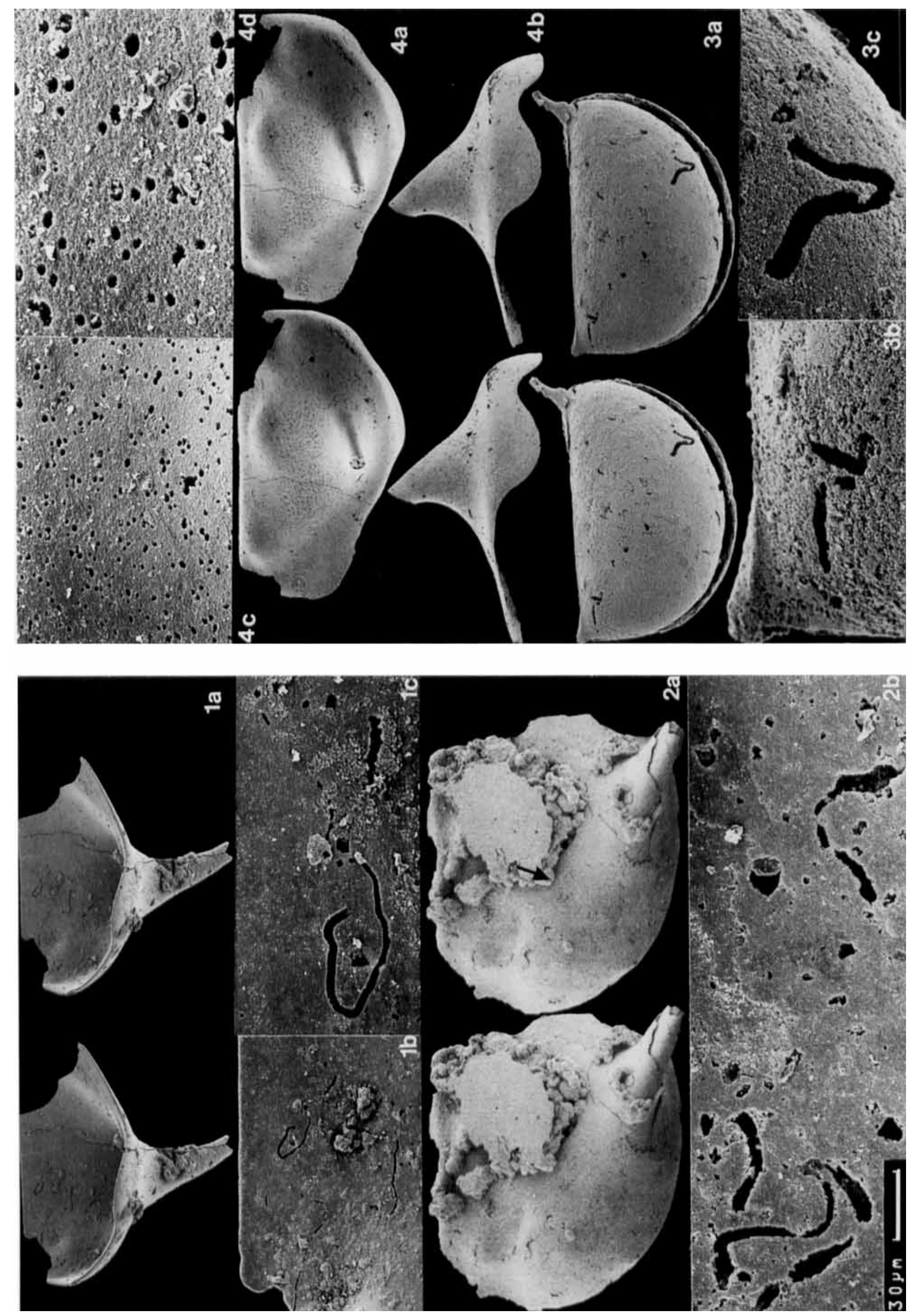
Diagnos is: Length at least up to $2.02 \mathrm{~mm}$. R/L overlap. Strong ventrolateral spine which seems to be dimorphic. In heteromorphs it is similar to a parrot's beak, in tecnomorphs it is slender with rounded cross-section. Larger instars and adults with free margin of both valves with a more or less broad ventral lappet below or slightly behind spine. OTP at about $0.90 \mathrm{~mm}$.

Description: The largest complete specimens reach a length of $2.0 \mathrm{~mm}(\mathrm{Pl} .3: 1)$ and $2.02 \mathrm{~mm}$ (MB.O. 319), but another posteriorly broken valve (Pl. 3: 2) must have been slightly larger. The carapace of this taxon is inequivalved with R/L overlap (Pl. 3: 5, Pl. 4: 2-3, Pl. 5: 1-3) and of subamplete (Pl. 3: 3) to distinctly preplete outline (Pl. 3: 6; Pl. 9: 4a). The maximum length of the valve occurs at about mid-height; the maximum convexity is located in the posterior-central field. The posterior end is flattened (Pl. 5: 1a; Pl. 9: 4a). The dorsal margin is straight. The anterior cardinal angle slightly exceeds $90^{\circ}$; the posterior cardinal angle is only little larger than the anterior one. A small hypocline dorsum is indistinctly set off from the lateral surface by a gentle bend (Pl. 5: 4). Between the dorsa a relatively broad interdorsum is developed. Its parallel interdorsal borders ('hinges') converge towards the cardinal corners passing into spines that are analogous to acroidal spines of post-Cambrian ostracods. Length of these spines is quite variable (Pl. 4: 4-9). However, the general trend agrees with what is known from "true" ostracods: small larvae carry particularly strong and comparably larger acroidal spines than later ontogenetic stages. The interdorsal borders are apparently the weakest portion of the carapace since the carapace is often folded in this area (P1. 4: 6). The free margin is unevenly developed: the anterior margin may be evenly rounded (Pl. 3: 1) or a little extended ventrally (e.g., Pl. 5: 1a). The ventral margin is evenly rounded or differentiated into a centroventral lappet (Pl. 5: 1a, Pl. 9: 4a); posteroventrally, the free margin may be slightly receding and may form a gentle angular extremity posteriorly (PI. 5: 1a). Admarginal sculptures are not developed. The interior is characterized by a broad doublure, posteriorly increasing in size where it may measure almost half the entire valve's width. On a single specimen, even the unmineralized inner lamella is observable (Pl. 1: 3), Lobation consists of three subdorsal nodes $\left(\mathrm{N}_{1}-\mathrm{N}_{3}\right)$, with $\mathrm{N}_{3}$ being distinct only in specimens longer than $1.50 \mathrm{~mm}$ (Pl. 3: 4; Pl. 5: 1a, 6; Pl. 9: 4a), another node
$\left(\mathrm{N}_{4}\right)$ in the anterior field and a very prominent $\mathrm{N}_{5}$. Subordinately, an additional node may be developed between $\mathrm{N}_{4}$ and $\mathrm{N}_{5}$ (Pl. 5: 5). $\mathrm{N}_{5}$ is developed as a large lateral spine and apparently of varying lengths even in small instars. This character is therefore regarded as variation rather than dimorphism. Due to allometric growth, the spine is located more posteriorly in small larvae than in larger ontogenetic stages (Pl. 3: 9b; Pl. 4: 7). In small larvae, the spine extends more vertically towards the contact plane, being only slightly directed posteriorly (Pl. 4: 4-9). However, development of the spine's shape seems to be a dimorphic character. Tecnomorphic individuals have a spine that extends almost perpendicularly to the lateral surface of the valve or that are somewhat posteriorly directed. Its cross-section is roughly circular. By contrast, heteromorphs are characterized by a strongly posteriorly curved spine that is laterally flattened, resembling a parrot's beak (PI. 1: 7; Pl. 3: 3,4 , ; Pl. 5: 6). The contact margin is evenly developed in small larvae ( $\mathrm{Pl}, 4: 5,7)$, but scalloped in larger stages with a centroventral and posteroventral concavity (Pl. 4: 2-3). The median lappet underneath the spine is the strongest extension and almost tongue-like (e.g., Pl. 3: 5, Pl. 9: 4b). Among totally closed carapaces (Pl. 4: 3) and completely opened specimens (Pl. 4: 2), there are also carapaces in only slightly opened position with still closed centroventral portion (Pl. 5: 1b,3). It is assumed that the primary openings in both anterior and posterior parts of the carapace served for continuous water supply.

Ontogeny: $V$. longispinosa exhibits a special kind of ontogeny in which the gestalt is very high to high in the smallest juveniles being $0.22-0.30 \mathrm{~mm}$ long. During early growth the gestalt becomes increasingly long, but from a carapace length of $0.90 \mathrm{~mm}$ onward, the $1: \mathrm{h}$ ratio decreases, resulting in valves that are higher (Fig. 8B). Whether or not this renewed increase in height is a continuous process is yet uncertain. According to the diagram (Fig. 8), a discontinuous process may be suggested. However, this could only be verified by complete and undistorted carapaces, and these are rather rare.

In post-Cambrian ostracods the gestalt remains either constant during ontogeny as, e.g., in the Ordovician Uhakiella jaanussoni skageni (Schallreuter 1973: Fig. 16) or Steusloffia costata (Schallreuter 1976: Fig. 12). In other taxa, the carapaces become higher during growth which results in a more elongated gestalt as in the Or- 


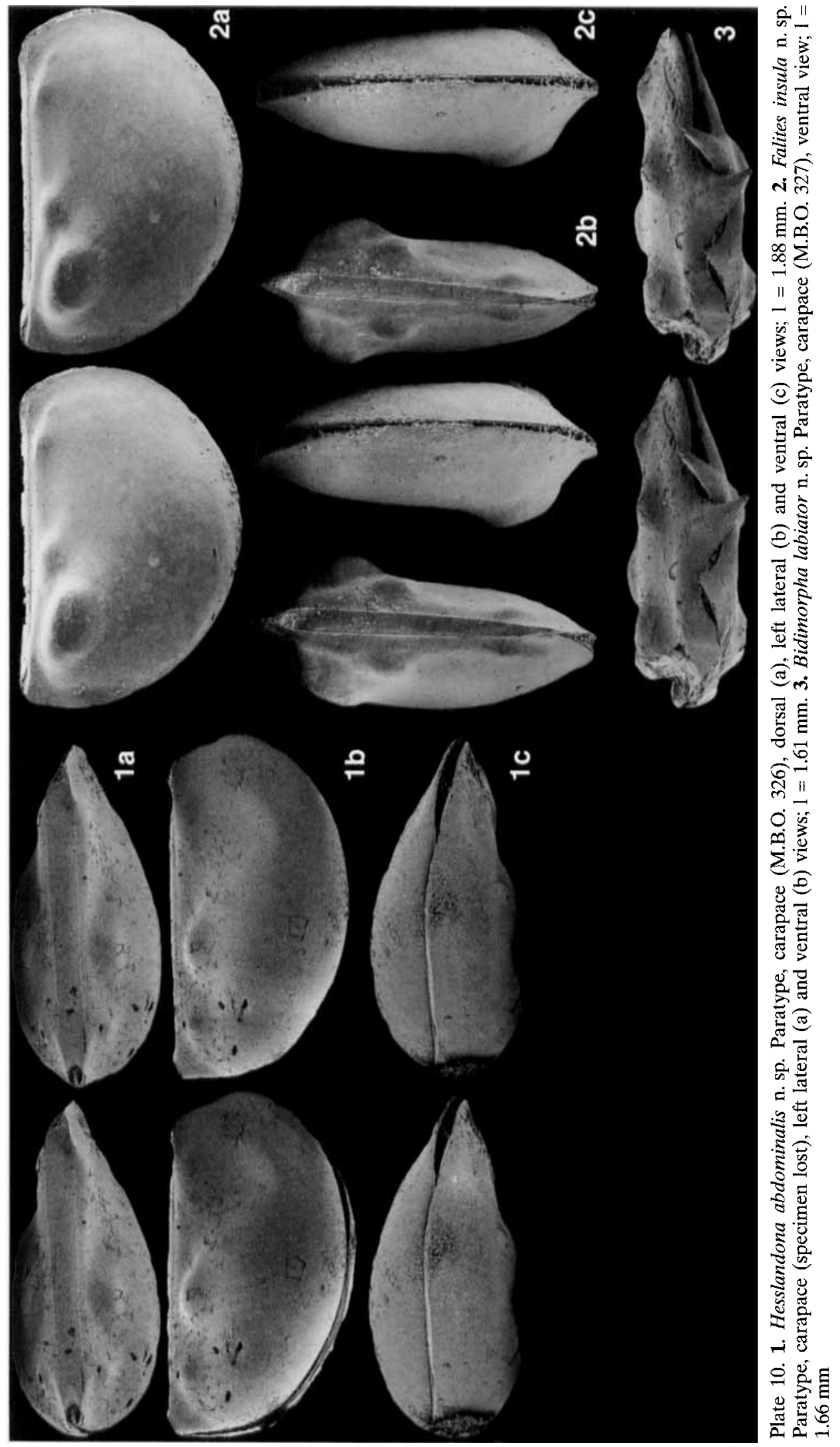


dovician Tetrada memorabilis (Schallreuter 1976: Fig. 4). An increase in height of the gestalt is unknown in post-Cambrian ostracods.

In the diagrams of Uhakiella and Steusloffia (see above), the gestalt also becomes slightly higher during early ontogeny. The material of these stages is very limited, and therefore it is uncertain whether or not we have here the same phenomenon as in $V$. longispinosa. More material is necessary to verify this possible feature.

Because of the unknown soft integument anatomy, the interpretation of the special ontogenic features is difficult. Information from the diagrams suggest, that the body grows mainly in length in early ontogentic stages. From the ontogenetical turning-point (OTP) onward, which occurs at about $0.90 \mathrm{~mm}$ for $V$. longispinosa, an increase in height is favoured with subsequent growth in both directions. The same phenomenon was observed in Falites fala with the OTP at about $0.60 \mathrm{~mm}$ (Hinz-Schallreuter 1996).

Another special feature of the ontogeny of $V$. longispinosa is the indistinctness of individual moult stages, a common character of Cambrian ostracods (Hinz-Schallreuter 1993a: 340).

Remarks: This taxon is exceedingly suitable for studies concerning intraspecific variation since it is well-characterized by its prominent lateral spine. The preservation of individual specimens is quite variable and covers complete specimens over partly demineralized (Pl. 3:6) to more or less crumbled carapaces (Pl. 3: 8; Pl. 4: 9 ). The latter is assumed to be a diagenetic feature rather than representing the situation shortly before or after the hatching process, since mineralisation or demineralisation of a carapace always starts marginally.

Most of the material described until now are juveniles. This refers to Kozur's holotype as well as to the material described by Hinz-Schallreuter (1993c) from Bornholm. More than 120 specimens from Andrarum with apparently few adults were studied by Williams et al. (1994). The relatively rich material from the Borregård Member of Bornholm, however, contains more adults which permit recognition of a yet unknown kind of sexual dimorphism in Cambrian ostracods.

\section{Vestrogothia minilaterospinata $\mathbf{n}$. sp.}

\section{Pl. 8, fig. 5}

Derivation of name: After the tiny ventrolateral spine.

Holotype: Carapace, MB.O. 321, Pl. 8: 5.

Type locality and type horizon: Same as for Hesslandona abdominalis.
Material: Figured specimen.

Diagnosis: Length up to at least $1.34 \mathrm{~mm}$. L/ R-overlap. Tiny ventrolateral spine located on a transversal line between $\mathrm{N}_{1}$ and $\mathrm{N}_{2}$. Free margin of larger valve with spine-like posteroventral protuberance.

Remarks: Similar to $V$. herrigi n. sp. this species is characterized by a spine-like posteroventral protuberance of the free margin. It differs from $V$. herrigi by the tiny lateral spine in a rather anterior position.

\section{Conclusions}

The Borregård phosphatocopes comprise eight species out of four genera and are the largest ever documented faunal association of Middle Cambrian phosphatocope ostracods. They come from a low energy environment which is indicated not only by excellent preservation without traces of abrasion and currency-induced fragmentation, but also by in situ findings of ostracod agglomerates, each consisting exclusively of juveniles of the same species. The ostracod populations contain mostly smaller to medium-sized growth stages. Very small individuals as well as the largest recorded instars are rather rare. Sexual dimorphism has been recognized only in Vestrogothia longispinosa. In the other two vestrogothiine taxa that belong to the genus Bidimorpha, sexual differentiations in carapace morphology could not be detected. In this respect, the Borregård community differs from Scanian ostracod associations that are characterized by two different Bidimorpha species, one of which clearly demonstrates sexual dimorphism (Bidimorpha bidimorpha Hinz-Schallreuter 1993a).

Concerning their outer gross morphology, the Borregård phosphatocopes are obviously benthic organisms which clearly show various adaptations to different life strategies. Lack of strong antennular muscles indicate that they had an epifaunal mode of life. The strong lateral spines in Vestrogothia served as some sort of cantilevers, and thus suggest life on the bottom of the seafloor. A similar, but not as efficient feature, is documented in the broad ventral surface of Hesslandona. By contrast, Bidimorpha arator seems to have developed its spine-like ventral stalks for some sort of anchorage on the ground, preventing the animals from being suck from behind by predatory worms. Partly interlocking ventral spines may have functioned as special clausal 
sculptures in order to prevent lateral shifting of the valves. This was obligatory for those taxa that are characterized by primary ventral openings in otherwise closed carapaces, guaranteeing continuous water and oxygen supply. Falitid ostracods with tear-shaped longitudinal cross-section resemble Extant ostracods, such as the genus Paradoxostoma which lives attached to seaweed. The softintegument anatomy of Falites (Müller 1982) however, suggests that it was a filter feeder, contrary to the sucking Paradoxostoma.

\section{Acknowledgements}

I am greatly indebted to all colleagues who catalyzed the study with technical support and scientific discussions. In particular I would like to thank my husband, R. Schallreuter (Hamburg) for general discussions and help with specific preparations. D. Keyser (Hamburg) and E. Pietrzeniuk (Berlin) gave me much valuable advice concerning detailed aspects in a comparison between Cambrian and Extant ostracods. Much technical help was supplied by various student helpers, e.g., L. Walder and H. Wulf (Hamburg), and M. Guerin (Berlin) who assisted in the course of extensive picking and sorting activities. Thanks are due to $\mathrm{M}$. and $\mathrm{P}$. Laurin (Toronto) for stylistic polishing of the manuscript. This investigation is part of a research project sponsored by the Deutsche Forschungsgemeinschaft which is greatfully acknowledged.

\section{References}

Barrande, J. 1872. Systême Silurien du centre de la Bohême

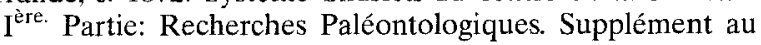
Vol. I. Trilobites, Crustacés divers et Poissons. - Texte: XXX +647 pp., 35 pls., Prague/Paris.

Becker, G. 1981. Ostracoda aus Cephalopoden-führendem Oberdevon im Kantabrischen Gebirge (N-Spanien). 1. Hollinacea, Primitiopsacea, Kirkbyacea, Healdiacea und Bairdiocypridacea. - Palaeontographica A 173: 1-63, pls. $1-11$.

- 1988. Tricorninidae (Ostracoda) aus der Wocklum-Stufe (hohes Oberdevon; Rechtsrheinisches Schiefergebirge). Geologisches Jahrbuch Hessen 116: 5-18.

Becker, G. \& Bless, M. J. M. 1990. Biotope indicative features in Palaeozoic ostracods: a global phenomenon. In Whatley, R. \& Maybury, C. (eds.) 1990. Ostracoda and Global Events. - British Micropalaeontological Society Publication Series: 421-436.

Berg-Madsen, V. 1981. The Middle Cambrian Kalby and Borregård Members of Bornholm, Denmark. - Geologiska Föreningens i Stockholm Förhandlingar $103(2=585)$ : 215-231, 8 Figs.

- 1985a. Middle Cambrian Biostratigraphy, Fauna and Facies in Southern Baltoscandia. - Acta Universitatis Upsaliensis Abstracts of Uppsala Dissertations from the Faculty of Science 781: (II+)37 pp.

- 1985b. A review of the Andrarum Limestone and the upper alum shale (Middle Cambrian) of Bornholm, Denmark. - Bulletin of the geological Society of Denmark 34 (3/4): 133-143.

Grönwall, K. A. 1902. Bornholms Paradoxideslag och deres Fauna. - Danmarks geologiske Unders øgelse (2) 13: XI $+231 \mathrm{pp}$

Groom, T. 1902. On Polyphyma, a New Genus belonging to the Leperditiadx, from the Cambrian Shales of Malvern.
- The Quarterly Journal of the Geological Society of London 58 (229): 83-88, pl. 3.

Gründel, J. \& Buchholz, A. 1981. Bradoriida aus kambrischen Geschieben vom Gebiet der nördlichen DDR. Freiberger Forschungshefte (C Geowissenschaften - Paläontologie) 363 [Beiträge zur Paläontologie, Stratigraphie und Palökologie; Festschrift AH Müller]: 57-73.

Guber, A. L. 1971. Problems Of Sexual Dimorphism, Population Structure And Taxonomy of The Ordovician Genus Tetradella (Ostracoda). - Journal of Paleontology 45(1): $6-22$.

Gürich, G. 1929. Silesicaris von Leipe und die Phyllokariden überhaupt. - Mitteilungen aus dem Mineralogisch-Geologischen Staatsinstitut 11: $21-90$.

Hicks, H. 1871. Descriptions of New Species of Fossils from the Longmynd Rocks of St. David's. - The Quarterly Journal of the Geological Society of London (I) 27 (4): $399-402$, pls. $15-16$.

Hinz, I. 1987. The Lower Cambrian Microfauna of Comley and Rushton, Shropshire/England. - Palaeontographica A 198 (1/3): $41-100$, pls. $9-23(1-15)$.

- 1991a. Ostrakoden aus kambrischen Geschieben. - Archiv für Geschiebekunde 1 (3/4): 231-234.

Hinz, I. C. U. 1991b. On Ulopsis ulula HINZ gen. et sp. nov. - A Stereo-Atlas Ostracod Shells 18 (2) 17: 69-72.

- 1992a. On Pejonesia sestina (FLEMING). - A Stereo-Atlas Ostracod Shells 19 (1) 2: 5-8.

- 1992b. On Semillia pauper HINZ gen. et sp. nov. - A Stereo-Atlas of Ostracod Shells 19 (1) 4: 13-16.

- 1993. Evolutionary trends in Cambrian ostracods. - Proceedings of the 11th International Symposium on Ostracoda, Warrnambool, Victoria, Australia 1991. In McKenzie, K. G. \& Jones, P. J. (eds.). Ostracoda in the Earth and Life Sciences: 3-12, 4 Fig, Balkema, Rotterdam.

Hinz-Schallreuter, I. 1993a. Ein mittelkambrischer hesslandonider Ostrakod sowie zur Morphologie und systematischen Stellung der Archaeocopa. - Archiv für Geschiebekunde 1 (6): $329-350$.

- 1993b. Ostracodes from the Middle Cambrian of Australia. - Neues Jahrbuch für Geologie und Paläontologie Abhandlungen 188 (3): 305-326.

- 1993c. Cambrian Ostracods Mainly from Baltoscandia and Morocco. - Archiv für Geschiebekunde 1 (7): 369, $370,385-448$.

- 1996. On Falites fala Müller. - A Stereo-Atlas of Ostracod Shells 23 (1/2) 20: 89-94.

- 1997a. Leben im Kambrium - die Welt der Mikrofossilien. In Zwanzig, M. \& Löser, H. (eds.) Berliner Beiträge zur Geschiebeforschung: 5-23, pls. 1-3, C-Press Verlag, Dresden.

- 1997b. Einsaugstutzen oder Auspuff? Das Rätsel um Yochelcionella (Mollusca, Kambrium). - Geschiebekunde aktuell 13 (4): II, 105-122.

Hinz, I. C. U. \& Jones, P. J. 1992. On Tubupestis tuber Hinz \& Jones gen. et sp. nov. - A Stereo-Atlas of Ostracod Shells 19 (1) 3: 9-12.

Hinz-Schallreuter, I. \& Koppka, J. 1996. Die Ostrakodenfauna eines mittelkambrischen Geschiebes von Nienhagen. - Archiv für Geschiebekunde 2 (1): 27-42.

Holm, G. 1893. Sveriges kambrisk-siluriska Hyolithidæ och Conulariidæ. - Sveriges Geologiska Undersökning (Ser. C Afhandlingar och uppsater) 112: IX +173 pp., 6 pls.

Hou Xianguang \& Bergström, J. 1997. Arthropods of the Lower Cambrian Chengiang fauna, southwest China. Fossils \& Strata 45: 116 pp.

Hou Xianguang, Siveter, D. J., Williams, M., Walossek, D. \& Bergström, J. 1996. Appendages of the arthropod Kunmingella from the early Cambrian of China: its bearing on the systematic position of the Bradoriida and the fossil record of the Ostracoda. - Philosophical Transactions of the Royal Society London (B) 351: 1131-1145.

Jaanusson, V. 1957. Middle Ordovician Ostracodes of Central and Southern Sweden. - Bulletin of the Geological Insti- 
tutions of the University of Uppsala $37(3 / 4): 173-442,15$ pls., 46 Figs, 40 tabs. (= Publications from the Palæontological Institution of the University of Uppsala $17=$ Dissertation University Uppsala), Uppsala.

Jones, P. J. \& McKenzie, K. G. 1980. Queensland Middle Cambrian Bradoriida (Crustacea): new taxa, palaeobiogeography and biological affinities. - Alcheringa 4: 203-225.

Jones, T. R. 1872. Note on the Entomostraca from the Cambrian Rocks of St. David's. - The Quarterly Journal of the Geological Society of London (I) 28 (2): 183-185, pl. 5, Figs16-18.

Kozur, H. 1974. Die Bedeutung der Bradoriida als Vorläufer der post-kambrischen Ostracoden. - Zeitschrift für Geologische Wissenschaften 2 (7): 823-830.

- 1985. Neue Ostrakoden-Arten aus dem oberen Mittelkarbon (höheres Moskovian), Mittel- und Oberperm des Bükk-Gebirges (N-Ungarn). - Geologisch-Paläontologische Mitteilungen Innsbruck, Sb. 2: 1-145, $22 \mathrm{pls}$.

Kummerow, E. 1931. Über die Unterschiede zwischen Phyllocariden und Ostracoden. - Centralblatt für Mineralogie, Geologie und Paläontologie B 1931 (5): 242-257.

Landing, E. 1980. Late Cambrian-Early Ordovician Macrofaunas and Phosphatic Microfaunas, St. John Group, New Brunswick. -- Journal of Paleontology 54 (4): 752-761.

Langer, W. 1973. Zur Ultrastruktur, Mikromorphologie und Taphonomie des Ostracoda-Carapax [On the Ultrastructure, Micromorphology and Taphonomy of the Ostracode Carapace]. - Palaeontographica A 144 (1/3): 1-54, pls. $1-15$.

Lochman, C. \& Hu, C.-H. 1960. Upper Cambrian Faunas from the Northwest Wind River Mountains, Wyoming. Part I. - Journal of Paleontology 34 (5): 793-834.

McKenzie, K. G., Müller, K. \& Gramm, M. N. 1983. Phylogeny of Ostracoda. In Schram F. R. (ed.). Crustacean Phylogeny: 29-46, Balkema, Rotterdam.

Müller, K. J. 1964. Ostracoda (Bradorina) mit phosphatischen Gehäusen aus dem Oberkambrium von Schweden. - Neues Jahrbuch für Geologie und Paläontologie (Abhandlungen) 121 (1): 1-46.

- 1981. Arthropods with phosphatized soft parts from the Upper Cambrian 'Orsten' of Sweden. - II International Symposium on the Cambrian System, U.S. Department of the Interior, Geological Survey Open-File Report 81-743: $147-151$.

- 1982. Hesslandona unisulcata sp. nov. with phosphatised appendages from Upper Cambrian "Orsten" of Sweden. In Bate, R. H., Robinson, E. \& Shephard, L.M. (eds.). Fossil and Recent Ostracods. - British Micropalaeontogical Society Series: $276-304,8$ pls., 6 Figs; E. Horwood, Chichester.

- 1983. Crustacea with preserved soft parts from the Upper Cambrian of Sweden. - Lethaia 16 (2): 93-109.

Müller, K. J. \& Walossek, D. 1991. Ein Blick durch das 〈Orsten)-Fenster in die Arthropodenwelt vor 500 Millionen Jahren (A view through the $\langle$ Orsten〉 window into the world of arthropods 500 Million years ago). - Verhandlungen der Deutschen Zoologischen Gesellschaft 84: $281-294$

Müller, K. J., Walossek, D. \& Zakharov, A. 1995. 'Orsten' type phosphatized soft-integument preservation and a new record from the Middle Cambrian Kuonamka Formation in Siberia. - Neues Jahrbuch für Geologie und Paläontologie (Abhandlungen) 197 (1): 101-118.

Poulsen, C. 1923. Bornholms Olenuslag og deres Fauna. Danmarks geologiske Unders $\emptyset$ gelse (II) 40: 83 pp.

Rushton, R. W. A. 1969. Cyclotron, a New Name for Polyphyma Groom. - Geological Magazine 106: 216-217.

- 1978. Fossils from the Middle-Upper Cambrian Transition in the Nuneaton District. - Palaeontology 21 (1): $245-283$.

Schallreuter, R. 1967. Neue Ostracoden aus ordovizischen Geschieben. - Geologie 16 (5): 615-631.
1973. Tvaerenellidae (Ostracoda, Palaeocopina) aus Backsteinkalk-Geschieben (Mittelordoviz) Norddeutschlands. - Palaeontographica A 144 (1/3): 55-111, pls. $16-25$.

- 1976. Ctenonotellidae (Ostracoda, Palaeocopina) aus Backsteinkalk-Geschieben (Mittelordoviz) Norddeutschlands. - Palaeontographica (Abteilung A Paläozoologie - Stratigraphie) 153 (4/6): 161-215, pls. 34-42.

- 1980. On Klimphores planus SCHALLREUTER. - A Stereo-Atlas of Ostracod Shells 7 (1) 2: 9-16.

- 1983. Glossomorphitinae und Sylthinae (Tetradellidae, Palaeocopa, Ostracoda) aus Backsteinkalk-Geschieben (Mittelordoviz) Norddeutschlands [Glossomorphitinae and Sylthinae (Tetradellidae, Palaeocopa, Ostracoda) from Backsteinkalk Erratic Boulders (Middle Ordovician) of Northern Germany]. - Palaeontographica A 180 (4/6): 126-191, pls. $15-29(1-15)$.

- 1984. Geschiebe-Ostrakoden I (Ostracodes from erratic boulders I). - Neues Jahrbuch für Geologie und Paläontologie (Abhandlungen) 169 (1): 1-40.

- 1987. Geschiebe-Ostrakoden II (Ostracodes from erratic boulders II). - Neues Jahrbuch für Geologie und Paläontologie (Abhandlungen) 174 (1): 23-53.

Shu Degan 1990. Cambrian and Lower Ordovician Bradoriida from Zhejiang, Hunan and Shaanxi Provinces. (6) + II + 95 pp., 20 pls., 46 Figs, Beijing.

Steusloff, A. 1895. Neue Ostrakoden aus Diluvialgeschieben von Neu-Brandenburg. - Zeitschrift der Deutschen Geologischen Gesellschaft 46 (4): 775-787, pl. 58.

Triebel, E. 1941. Zur Morphologie und Ökologie der fossilen Ostracoden. Mit Beschreibung einiger neuer Gattungen und Arten. - Senckenbergiana 23 (4/6): 294-400.

Tullberg, S. A. 1880. Om Agnostus-Arterna i de kambriska aflagringarne vid Andrarum.. - Sveriges Geologiska Undersökning (C) 42: (I+) 38 pp., 2 pls., 2 tabs. (1 sep.), 1 sep. map.

Ulrich, E. O. \& Bassler, R. S. 1931. Cambrian Bivalved Crustacea of the Order Conchostraca. - Proceedings of the United States National Museum $78(4=2847)$ : $130 \mathrm{pp}$., 10 pls.

Walossek, D., Hinz-Schallreuter, I., Shergold, J. H. \& Müller, K. J. 1993. Three-dimensional preservation of arthropod integument from the Middle Cambrian of Australia. Lethaia 26 (1): $7-15$.

Walossek, D. \& Müller, K. J. 1990. Upper Cambrian stemlineage crustaceans and their bearing upon the monophyletic origin of Crustacea and the position of Agnostus. Lethaia 23: 409-427.

- 1991. 'Orsten' arthropods - small in size but of great impact on biological and phylogenetic interpretations. GFF 113 (1): 88-89.

- 1992. The 'Alum Shale Window' - Contribution of 'Orsten' Arthropods to the Phylogeny of Crustacea. - Acta Zoologica 73 (5): 305-312.

Whatley, R., Ayress, M., Downing, S., Harlow, C. \& Kesler, K. 1985. Aratrocypris, an enigmatic new cyprid ostracod from the Tertiary of D.S.D.P. sites in the S.W. Pacific. Journal of Micropalaeontology 4 (2): 69-79.

Williams, M., Siveter, D. J., Berg-Madsen, V. \& Hinz-Schallreuter, I. 1994. On Vestrogothia longispinosa KOZUR A Stereo-Atlas of Ostracod Shells 21 (1) 6: 21-16.

Williams, M, Siveter, D. J., Rushton, A. W. A. \& Berg-Mad sen, V. 1994. The Upper Cambrian bradoriid ostracod Cyclotron lapworthi is a hesslandonid. - Transactions of the Royal Society of Edinburgh (Earth Sciences) $\mathbf{8 5}$ : $123-130$.

Wills, M. A., Briggs, D. E. G., Fortey, R. A. \& Wilkinson, M. 1995. The significance of fossils in understanding arthropod evolution. - Verhandlungen der Deutschen Zoologischen Gesellschaft 88 (2): 203-215.

Zhang Xiguang 1987. Moult stages and dimorphism of Early Cambrian bradoriids from Xichuan, Henan, China. - Alcheringa 11: $1-19$ 